\title{
La Transacción
}

Felipe Osterling Parodi ${ }^{1}$

Mario Castillo Freyre

\section{¿Se puede hablar de un medio idóneo de extinción de obligaciones?}

Al iniciar nuestros comentarios acerca de la transacción como medio extintivo de las obligaciones, es preciso tener en claro los atributos de las demás figuras extintivas, ya que la transacción reviste mayor complejidad y riqueza, por lo que suele ser objeto de confusión y, eventualmente, de conceptos erróneos.

No obstante esta afirmación, no caeremos en el lugar común de sostener que la transacción constituye (después del pago, en estricto) la figura extintiva más relevante, pues todos los medios extintivos tienen igual importancia, como también ocurre con los contratos de toda clase. La mayor o menor complejidad, así como la mayor o menor frecuencia en su empleo, no hacen a una figura o institución necesariamente más o menos importante que las demás, puesto que en el momento y caso específico en que es necesaria y se acude a ella, en ese preciso instante esa es la más importante de todas, ya que en principio ninguna otra podría cumplir sus objetivos concretos. Cualquier modo de realizar actos jurídicos al amparo de la autonomía privada reviste, en todos los casos, el mayor interés.

l Los autores agradecen a la doctora Roxana Jiménez Vargas Machuca por su valiosa colaboración. 
Si bien se considera que el pago es el medio extintivo de las obligaciones idóneo por excelencia, y hasta se le reputa como el más importante, en realidad solo lo es en términos relativos, por implicar que la prestación objeto de la obligación se ejecuta de acuerdo a los términos convenidos originalmente, lo que determina la extinción de la relación obligatoria. Decimos que sólo en términos relativos el pago constituye el medio de extinción ideal, porque muchas veces a una de las partes o incluso a ambas les es más conveniente recurrir a otro tipo de solución.

En efecto, no es extraño que varíen las circunstancias entre la celebración del contrato y el comienzo de su ejecución. Estas circunstancias pueden corresponder tanto al ámbito personal de los propios contratantes, como a situaciones externas que influyan directamente sobre la relación contractual habida entre ambos. Y no nos referimos únicamente a la imposibilidad de cumplimiento ${ }^{2}$ o a los supuestos que conducen a una excesiva onerosidad de la prestación ${ }^{3}$, sino a que las partes decidan que un cambio es necesario o deseable dentro de lo acordado. O que en términos del análisis económico del Derecho, sea más ventajoso incumplir (teoría del incumplimiento eficiente), es decir, que el "rompimiento" del contrato se considere más eficiente que su cumplimiento en los casos en que el costo exceda los beneficios de su cumplimiento para todas las partes involucradas. Esto ocurre cuando surge una contingencia (inesperada, por cierto) que cambia la situación de tal forma que los recursos necesarios para cumplir la prestación sean más valiosos en otro uso alternativo. Este no constituirá un modo formal de extinción de obligaciones, pero se trata de una fuente de las

2 Artículo $1431^{\circ}$ del Código Civil.- «En los contratos con prestaciones recíprocas, si la prestación a cargo de una de las partes deviene en imposible sin culpa de los contratantes, el contrato queda resuelto de pleno derecho. En este caso, el deudor liberado pierde el derecho a la contraprestación y debe restituir lo que ha recibido.

Empero, las partes pueden convenir en que el riesgo esté a cargo del acreedor."

3 En nuestro ordenamiento civil, si en los contratos conmutativos de ejecución continuada, en los contratos conmutativos de ejecución inmediata (cuando la prestación a cargo de una de las partes ha sido diferida por causa no imputable a ella), o en los contratos aleatorios (cuando la excesiva onerosidad se produce por causas extrañas al riesgo propio del contrato), la prestación llegase a ser excesivamente onerosa por acontecimientos extraordinarios e imprevisibles, la parte perjudicada tiene la facultad de solicitar al juez que la reduzca o que aumente la contraprestación, a fin de que cese la excesiva onerosidad. Pero si esta solución no fuera posible debido a la naturaleza de la prestación, a las circunstancias, o si lo solicitara el demandado, el juez puede decidir por la resolución del contrato. 
obligaciones (es el caso de que la parte prefiera asumir la responsabilidad derivada de su incumplimiento, resarciendo a su contraparte, que cumplir la obligación, lo cual le resultaría menos beneficioso) que, finalmente, conducirá a una extinción de las obligaciones originalmente creadas por contrato.

De igual forma, una persona puede considerar más provechoso, satisfactorio o deseable (las razones son de toda índole) no recibir la contraprestación que se le adeuda, y por ello condonar la obligación de su deudor (naturalmente con asentimiento de éste) en lugar de hacer efectivo el pago. En este caso, tal vez el más extremo dentro de los modos de extinción de obligaciones (por romper con la estructura del synallagma y desigualar las prestaciones), resulta que no es el pago el modo idóneo, sino exactamente lo opuesto, vale decir, el no pago.

Por ejemplo, el pago se vuelve un pésimo modo de extinción cuando se dan los requisitos necesarios para oponer una compensación. Precisamente la compensación tiene como finalidad evitar un inútil doble pago, así como cumplir una singular función de garantía.

$Y$ hablando de inutilidad e ineficiencia y, desde luego, de imposibilidad en los modos de extinción de las obligaciones, el ejemplo más claro es el de la consolidación. Suponer que el pago podría ser adecuado en este contexto sería simplemente irracional.

En cuanto a la novación (particularmente en su aspecto objetivo, ya que el subjetivo es poco frecuente), ella constituye una de las figuras de mayor uso en la práctica, a pesar de que cuando se presenta, con mucha frecuencia pasa inadvertida para las partes. Por tal circunstancia, muchas veces no existe conciencia por la sociedad en general sobre la importancia de este medio extintivo y, a la vez, creador de obligaciones.

Por otro lado, es evidente que el mutuo disenso en ciertos casos constituye la solución ideal para los contratantes, ya que ocasionalmente el pago recíproco podría ser perjudicial para ellos.

Resumiendo, a pesar de que con frecuencia hemos oído decir que el pago, en estricto, es el modo "idóneo" de extinción de obligaciones, en el terreno práctico no hay un solo modo idóneo de extinción de obligaciones, salvo el que corresponda a cada caso en particular. Afirmar lo contrario determinaría, por ejemplo -y en un plano analógico-, que pudiera considerarse al contrato de compraventa como más idóneo que el contrato de obra o que el contrato de hospedaje. 
Estas reflexiones iniciales obedecen a que continuamente se someten las figuras del Derecho a comparaciones entre sí, y consideramos que resulta oportuno zanjar esta cuestión, ya que de existir -en cualquier ámbito- una figura idónea, las demás no tendrían razón de existir, y eso, a todas luces, constituiría una falacia.

\section{Importancia de la transacción}

La transacción, como mencionamos al inicio de este trabajo, es una figura bastante compleja, tal vez la más compleja dentro de los modos de extinción de obligaciones. Comentaremos acerca de su importancia en la vida práctica, además de las doctrinas que la han delimitado, su tratamiento en el Código Civil y sus relaciones y regulación en el Código Procesal Civil.

No dudamos en afirmar que la importancia práctica de la transacción es enorme, puesto que no sólo se trata de un medio extintivo de obligaciones, sino que comprende aspectos particulares que la delimitan como una de las figuras más ricas y complejas de nuestro ordenamiento jurídico. Su utilidad, por otra parte, ha venido siendo asumida por la sociedad en general, ya que las personas suelen recurrir a la transacción para solucionar sus controversias.

Todos conocemos la antigua y siempre vigente frase "Más vale un mal arreglo que un buen juicio". Ignoramos sus orígenes; es más, tal vez resulte imposible determinarlos. Pero de lo que sí estamos seguros es que quien la pronunció por primera vez debe haber conocido lo complejo, costoso e incierto de un proceso judicial.

$\mathrm{Y}$ aunque el verdadero Derecho, el Derecho vivo, se halla en el sistema judicial, ya que es ahí donde se administra justicia, lamentablemente en sociedades tan grandes, dinámicas, pluriculturales y heterodoxas, este importantísimo órgano se encuentra singularmente recargado y con frecuencia no responde a los requerimientos y demandas privadas. Es por ello que cobra utilidad e importancia, cada vez con mayor ímpetu, la transacción.

No obstante que hasta en este mismo siglo se ha considerado como poseedora de un toque de distinción a aquella persona de clase socio económica alta (segmento "A», como hoy en día se le denomina) que se mantenía como litigante (lo cual elevaba su status), en términos 
generales todos saben -y sabian- que un proceso judicial implica sacrificios económicos muchas veces no recuperables, y particularmente el gasto más oneroso: el tiempo. Por otro lado, es vocación de la gran mayoría de seres humanos convivir de manera pacífica, lo que se perturba con la proliferación de litigios. Dentro de esta situación de conflicto y disputa, no sólo se ve afectado el patrimonio de los litigantes, sino en ocasiones hasta su salud física y mental. Finalmente, cabe la posibilidad de que una de las partes (o incluso ambas) queden insatisfechas con los resultados del proceso.

La transacción en materia procesal no sólo ayuda a las partes a solucionar sus diferencias en un juicio, sino también en un arbitraje, al cual hubieran podido recurrir, justamente en la búsqueda de obtener justicia de un modo más expeditivo. Sin embargo, los gastos en que incurren las partes no distan mucho en uno y otro caso, ya que por lo general tanto los honorarios profesionales de los árbitros miembros del tribunal arbitral como los gastos administrativos de la entidad encargada de organizar y supervisar el arbitraje, son considerables.

Como es evidente, el malestar de las partes se origina cuando éstas se encuentran en abierta discrepancia sobre algún tema o problema relativo a sus relaciones civiles, comerciales o de cualquier otra índole. A ambas les resulta conveniente -en muchos casos- solucionar sus diferencias de una manera amistosa y responsable, lo que ocurrirá con mayor frecuencia cuando las dos tengan claro que les asiste recíprocamente algo de razón, y que en un proceso judicial o arbitral una de ellas podría resultar victoriosa en un cien por ciento, lo cual implicaría una situación de pérdida absoluta para la otra. De esta forma, muchas veces puede resultar más sensato transigir antes que optar por la vía del proceso judicial o arbitral.

Asimismo, en términos generales, la transacción constituye un componente altamente relevante en la vida diaria de los seres humanos, entendida en un sentido que excede la acepción estrictamente jurídica de la palabra. La cotidianeidad en términos sociales implica que cada uno de nosotros transija permanentemente, al tolerar conductas o comportamientos de aquellas personas que nos rodean o con quienes tenemos que tratar o convivir. Siendo el hombre un ser básicamente social, no hacerlo lo obligaría a recluirse en una especie de voluntario ostracismo. No hay transacciones ni Derecho en la isla de Robinson. Vivimos transando y porque transamos sobrevivimos. 
El propósito del legislador de 1984 de robustecer la transacción, dándole un tratamiento detallado, ha sido facilitar a las partes un medio adecuado para solucionar sus diferencias, es decir, que la transacción constituya uno de los mecanismos ágiles de solución de conflictos sin la intervención de los tribunales de justicia. Por medio de la transacción las partes "se dictan su propia sentencia", ahorrándose los costos (de toda índole) que implica un proceso.

Atendiendo a estas razones de celeridad, economía y eficiencia, el actual código amplió el ámbito de la transacción, y de esta forma se ha abierto la posibilidad para que las partes resuelvan sus diferencias, siendo lo más resaltante el que puedan comprender en la transacción a todas sus relaciones jurídicas, sean o no extrañas a la controversia y aun cuando fueren pacíficas. Cabe destacar que se ha otorgado mérito ejecutivo a la transacción celebrada fuera de juicio.

Un aspecto primordial lo constituye el hecho de que la ley peruana no admite la lesión en la transacción, en caso que hubiese desproporción entre las concesiones recíprocas, puesto que no se exige que las mutuas concesiones sean equivalentes. De esta forma se impide que lo perseguido con esta figura (evitar que un juicio se promueva o prosiga) se pierda por la vía de la lesión, ocasionando a la larga mayores inversiones en tiempo y dinero, y obstaculizando que se cumpla el cometido de la transacción. Según el razonamiento del legislador peruano, admitir la lesión en estos casos importaría reabrir un debate judicial sobre la cuantía de las concesiones mutuas que se hicieran las partes para arribar a la transacción. Sin embargo, tal como se verá más adelante, hay lugar a abrir una discusión sobre los alcances y pertinencia de la prohibición a que estamos haciendo referencia.

Otro cambio introducido en mérito a la importancia de la transacción dentro de las relaciones civiles es el haber atenuado el requisito de forma necesario para su celebración, el cual en el código vigente es que ella conste por escrito (bajo sanción de nulidad), sin requerirse la formalidad de la escritura pública, considerada por algunos autores como ad solemnitatem, que exigía el Código Civil de 1936.

La doctrina francesa de los exégetas reputaba a este contrato como uno de los más útiles entre aquellos establecidos en el Código (Codex) de Justiniano y en el Corpus Iuris Civilis, debido a que gracias a él los procesos podían evitarse o terminar amablemente, y así los asuntos que envolvían los intereses más discordantes y ardientes llegaban a resolver- 
se con sentimientos pacíficos. El principio que justifica la existencia de la transacción se reduce, pues, al beneficio de la paz y la tranquilidad, la cual se pierde en los procesos tormentosos: Melior est certa pax quam sperata victoria. Por ello es que las leyes le reconocen una autoridad semejante a la judicial.

A decir verdad, la importancia de la transacción es enorme, ya que se extiende, como hemos señalado, a todas las esferas privadas cotidianas, comerciales y hasta al Derecho Internacional, pues los tratados y acuerdos internacionales (en particular los de paz) son verdaderas transacciones en las que los países, luego de delinear los intereses comunes y determinar los asuntos en conflicto, abandonan o suavizan sus posiciones originales y realizan concesiones recíprocas, y así solucionan sus discrepancias.

El Código Civil chileno, en el artículo $246^{\circ}$, define a la transacción como un contrato en que las partes terminan extrajudicialmente un litigio pendiente, o previenen un litigio eventual. Sobre la trascendencia de la transacción en ámbitos mayores a éste, Alvaro Ortúzar Santa María señala que la transacción no se distingue sólo por ser un contrato de carácter privado, como tantos otros que reglamenta el código civil, ni tampoco su único objeto es terminar extrajudicialmente un litigio pendiente o precaver un litigio eventual. En realidad, la transacción es en el fondo un significativo gesto de paz, cuya esencia consiste en aceptar, recíprocamente, parte de una pretensión contraria que en principio se rechazaba por injusta, irracional o falsa, obteniendo, a cambio, certeza jurídica y estabilidad permanentes.

El citado profesor pone énfasis en el ambiente psicológico especial en el que se forma el consentimiento necesario para dar vida a la transacción, el cual por cierto es muy distinto al ambiente que se respira al demandar judicialmente. Las partes habían evolucionado interiormente a un estado de anormalidad en las relaciones humanas como es el de beligerancia, lo cual exige, desde luego, realizar una calificación jurídica de los hechos que motivan la controversia y, en seguida, una calificación moral o ética de la conducta de la otra parte. Sólo después de ello se demanda o se está decidido a demandar. Y ocurre que la tran-

4 Alvaro Ortuzar Santa María. "Nulidad del Contrato de Transacción en Materia Civil": En: Enrique Bartos Bourie. Contratos. Editorial Jurídica de Chile, Santiago de Chile, 1991, pp. 23 у 24. 
sacción detiene ese proceso y lo transforma en un gesto de paz, donde la voluntad avanza en forma inversa a su dirección original, hasta terminar por aceptar parte de lo que antes se repudiaba por injusto, irracional o falso.

A modo de resumen, diremos que la transacción es un contrato cuya finalidad es resolver un conflicto por las propias partes mediante concesiones recíprocas. Entonces, su incidencia se encuentra en dos niveles: en la forma y en el fondo. A nivel formal, la transacción, siendo un contrato, apunta mucho más a zanjar cuestiones ya existentes entre las partes, es decir, a extinguir relaciones jurídicas existentes que se encuentran en controversia. Por ello su ubicación es más clara dentro de los medios extintivos de las obligaciones. En cuanto al nivel de fondo, lo que subyace en el corazón de esta figura se centra en la búsqueda de paz y armonía.

Etimológicamente, la palabra "resolver" proviene del latín resolvere, que significa aclarar, solucionar, solventar. Y es ésa la finalidad primordial de la transacción: resolver uno o varios problemas que se han suscitado entre las partes. Y tal búsqueda de soluciones al conflicto implica un ánimo que da pie a las concesiones recíprocas, ya que de lo contrario, existiendo conflicto y ninguna intención de ceder, no hay cabida a transacción alguna; las partes en ese caso preferirían iniciar o continuar con la disputa judicial. Recordemos que un factor importante que inclina la balanza hacia la decisión de intentar transar, lo constituye la dosis de incertidumbre en el fururo.

Cada una de las partes, por su propia cuenta, realiza su personal análisis costo-beneficio respecto de lo que implica conservar el problema, llevarlo a los tribunales, continuar el proceso ya iniciado, o procurar arribar a una transacción (lo que implica ceder en algunos aspectos), etc. Dentro de las variables que manejan las partes en este análisis se encuentran las leyes, los informes de los respectivos abogados, los informes de peritos (especialistas), el seguimiento estricto de los requisitos procesales de forma, la jurisprudencia, la doctrina, así como afrontar gastos, demoras, malos ratos, temores $y$, muy especialmente, la terrible incertidumbre acerca del fallo de los tribunales. A menos que una de las partes tenga la "absoluta certeza" de ganar el juicio ${ }^{5}$, es decir, que

5 Estamos colocando el supuesto en sentido figurado, ya que nunca se puede tener, en estricto, la «absoluta certeza» de que se va a ganar un juicio, pues numerosos factores están 
carezca del elemento de incertidumbre, o que el problema tenga un trasfondo de índole personal ${ }^{6}$, lo más probable es que ambas prefieran, por considerarlo más eficiente, llegar a un acuerdo.

Es entonces cuando las partes deciden buscar entre ellas mismas la solución a su controversia. En el manejo y desarrollo de sus conversaciones conducentes a encontrar una salida pacífica al conflicto conjugarán los elementos antes mencionados, además de sus intereses concretos, sopesando la ubicación y trascendencia de cada uno hasta que se arribe a la fórmula de satisfacción mutua en que la controversia se acabará definitivamente.

Para concluir este tema señalaremos que, en síntesis, la esencia de la transacción reside en una relación jurídica incierta y controvertida, susceptible de derivar en litigio o ya latente judicialmente, la misma que las partes deciden llevar a término en forma definitiva. De esta manera, encausan su voluntad a esa finalidad a través de concesiones recíprocas. Esta última característica, a saber la voluntad de prevenir o terminar un litigio judicial, traducida en concesiones recíprocas, es lo que distingue a la transacción, no solamente de los demás modos de extinción de obligaciones, sino de los otros contratos, aparte de todas las otras formas de conclusión de una controversia, como son, por ejemplo, la sentencia judicial, el allanamiento, el desistimiento de la demanda, el reconocimiento de títulos y hasta el advenimiento o conciliación.

\section{Concepto}

La Real Academia de la Lengua Española ${ }^{7}$ define a la transacción como "acción y efecto de transigir», y por extensión «trato, convenio, negocio".

supeditados al fallo, entre otros, la probanza. Por otro lado, hay una antigua máxima que reza "en un juicio no basta tener la razón sino que te la quieran dar».

6 Aunque aun en este caso es dificil que la parte que se siente más "segura" se encuentre en condiciones de afrontar el gasto mayor de un procedimiento judicial, que está constituido básicamente por la prolongada demora en el tiempo.

7 Real Academia de la Lengua Española. Diccionario de la Lengua Española, Tomo II, Espasa Calpe S.A., Madrid, 1984, p. 1330. 
Transigir $^{8}$ se define como "consentir en parte con lo que no se cree justo, razonable o verdadero, a fin de llegar a un ajuste o concordia, evitar algún mal, o por mero espíritu de condescendencia». También como "ajustar algún punto dudoso o litigioso, conviniendo las partes voluntariamente en algún medio que componga y parta la diferencia de la disputa.»

De este mismo parecer es Guillermo Cabanellas ${ }^{9}$, quien define a la transacción, en su primer significado, como "concesión que se hace al adversario, a fin de concluir una disputa, causa o conflicto, aun estando cierto de la razón o justicia propia.»

El Código Civil peruano de 1984 también adopta un concepto restringido de transacción, pues cuando utiliza este término se refiere a un medio extintivo de obligaciones, y no lo emplea en su acepción más amplia, esto es como negocio o acuerdo entre las partes.

La transacción ya existía en el Derecho romano y su denominación actual deriva del verbo latino transigere, que significa arreglar una controversia, o concluirla de común acuerdo de partes. Aunque, como hemos ya expresado, en el sentido vulgar se aluda con el vocablo «transacción" a toda clase de convenciones, en su significado jurídico estricto, coincidente con su etimología, se designa al acto jurídico cuya finalidad inmediata es la de extinguir obligaciones o relaciones jurídicas litigiosas o dudosas.

El artículo $832^{\circ}$ del Código Civil argentino define a la transacción como "un acto jurídico bilateral, por el cual las partes, haciéndose concesiones recíprocas, extinguen obligaciones litigiosas o dudosas". Luis de Gásperi ${ }^{10}$, comentando este precepto, el mismo que fue inspirado en la obra de Aubry y Rau y en el artículo $1196^{\circ}$ del Proyecto de Freitas, manifiesta que se resiente de la insuficiencia que se ha hecho notar en el artículo $2044^{\circ}$ del Código Civil francés, en cuanto limita los fines de la transacción a extinguir obligaciones litigiosas ya nacidas o a precaver litigios eventuales ${ }^{11}$.

8 En América Latina se utilizan indistintamente como sinónimos los términos transigir y transar, siendo esta última palabra también parte de la Lengua Española (Real Academia de la Lengua Española. Op. cit., Tomo II, pp. 1330 y 1331).

9 Guillermo Cabanellas. Diccionario Enciclopédico de Derecho usual, Tomo VIII, Editorial Heliasta S.R.L., Buenos Aires, 1982, pp. 163-165.

10 Luis De Gasperi. Tratado de las Obligaciones en el Derecho Civil Paraguayo y Argentino, Tomo III, Editorial De Palma, Buenos Aires, 1945 a 1946, pp. 213-214.

11 Este autor considera que la transacción podría (y debería) tener por objeto no sólo 
En su acepción cotidiana, la palabra transacción se emplea para designar toda clase de convenciones. Como manifestamos al inicio de este trabajo, se transige diariamente, en muchos ámbitos; por ejemplo, se habla en este sentido de las transacciones de la Bolsa, de transacciones financieras, de la industria o del comercio, etc. Pero en su sentido jurídico, si bien en cuanto al fondo hay identidad en la definición, la palabra transacción tiene un alcance bastante más restringido, puesto que lo enfoca a un acto jurídico cuya finalidad es resolver mediante concesiones recíprocas (a las que el argentino Joaquín Llambías denomina "intercambio de sacrificios o renunciamientos"), sobre un asunto dudoso o litigioso, es decir, llegar a un acuerdo en que ambas partes se sientan satisfechas para obtener la certidumbre acerca de un derecho o relación jurídica pendiente. En otras palabras, la transacción, como acto jurídico que es, debe reunir condiciones legales específicas a su caracterización, además de las que son comunes a cualquier acto jurídico.

Estas características particulares son la objeción sobre la relación jurídica (como el profesor brasileño Levenhagen llama a los asuntos dudosos o litigiosos) y las concesiones mutuas o recíprocas. Ambas características constituyen el eje sustancial (y no meramente formal) de la figura.

Hay códigos civiles que plasman este aspecto. Por ejemplo, el Código Civil alemán (BGB) es bastante expresivo al mencionar el factor incertidumbre sobre su relación jurídica, elemento sustancial para entender el concepto e importancia de la transacción ${ }^{12}$. Asimismo, el Código Polaco de las Obligaciones también incide sobre este aspecto psicológico, crucial para la existencia de la transacción ${ }^{13}$.

Podemos concluir que por medio de la transacción, las partes transforman un status jurídico inseguro por otro seguro, a través de sus mutuas concesiones.

relaciones jurídicas obligatorias, sino también las reales, familiares o sucesorias que estén dentro de las facultades de disposición de las partes, y puede además mirar a su reconocimiento y cumplimiento. De esta forma no podrá, desde luego, transigirse sobre la existencia o validez del matrimonio, materia ajena a las facultades de disposición de los particułares.

12 En su artículo $779^{\circ}$, el BGB define a la transacción como un acuerdo por el que se termina por recíprocas concesiones un litigio o la incertidumbre de las partes sobre una relación de derecho.

13 En su artículo $621^{\circ}$, el Código Polaco de las Obligaciones establece que las concesiones recíprocas pueden tender a concluir un litigio existente, prevenir un litigio a producirse, suprimir la incertidumbre respecto de las pretensiones derivadas de una relación jurídica o asegurar su realización. 


\section{Naturaleza jurídica}

Respecto a la naturaleza jurídica de la transacción, existen tres posiciones que intentan explicarla en función del ángulo desde el que la enfocan. Una primera considera que es un contrato o una convención; una segunda estima que se trata de un acto jurídico bilateral; y una tercera, a la que se adhiere el Código Civil peruano de 1984, la ubica como un medio extintivo de obligaciones.

\section{(a) La transacción como contrato.}

Parte importante de la doctrina y de la legislación ${ }^{14}$ de nuestra tradición jurídica considera a la transacción como un contrato, sujeto a las disposiciones de carácter general que rigen a éstos (la capacidad, el objeto, el modo, la forma, la prueba y la nulidad).

En general se concuerda, sobre este punto, que el origen de la transacción como contrato se encuentra en el artículo $2044^{\circ}$ del Code, norma positiva que la define como un contrato en el que se da una renuncia recíproca de las partes. No se trata de una renuncia simple, ni de un desistimiento, ni de una condonación, sino de un sacrificio mutuo de las partes respecto a sus pretensiones, es decir, de concesiones recíprocas. De esa forma, la transacción no es otra cosa que un contrato consensual, bilateral (es decir, sinalagmático), declarativo y no traslativo de derechos, indivisible (no admite nulidades parciales) y que en cierta medida participa de los caracteres de la cosa juzgada.

Pero es conveniente anotar que su verdadero origen se remonta a los romanos, para quienes las concesiones recíprocas eran un requisito de adquisición de un derecho indiscutible mediante la transacción (transactio, nullo dato, vel retento seu promisso, minime procedit) ${ }^{15}$.

14 A modo de ejemplo, podemos mencionar los siguientes códigos: el francés (artículos $2044^{\circ}$ a $2058^{\circ}$ ), el alemán (artículo $779^{\circ}$ ), el polaco de las Obligaciones (artículo $621^{\circ}$ ), el italiano de I 942 (artículo 1965\%), el venezolano de 1942 (artículos $1713^{\circ}$ a 1723), el mexicano de 1927 (artículo 2944\%), el uruguayo (artículo 2147\%), el chileno, el boliviano de 1976, el Proyecto de Reforma Argentino de 1936, etc.

15 Recordemos que el concepto de sinalagma proviene de la filosofía griega, como premisa primordial de la justicia conmutativa, la misma que formaba parte del concepto de justicia particular que concibió Aristóteles. Los romanos tomaron este y otros conceptos, como sabemos, de las concepciones griegas de justicia. 
Quienes ubican a la transacción dentro de los contratos y no dentro de los modos de extinción de las obligaciones, señalan que la transacción no se limita a esta última función, sino que, por el contrario, puede tener por objeto que las obligaciones se cumplan y reconozcan. $Y$ en este punto no les falta razón.

Sin embargo, el definir a la transacción como un contrato en algunos casos ha sido dejado de lado, como en Argentina. Así, el Proyecto de la Comisión Argentina de Reformas al Código Civil, en su artículo $1342^{\circ}$, ubicaba a la transacción como un contrato, pero Vélez Sarsfield, influido por la autoridad del Código Austríaco (artículo $1380^{\circ}$ ), del Landrecht Prusiano, y del Proyecto de Freitas (artículo 1196\%), se apartó de aquel método. Siguiendo la línea de aquéllos, es decir, concibiendo a la transacción como un acto jurídico (cuya noción va más allá que la del contrato), Vélez Sarsfield la ubicó inmediatamente después de la confusión (para nosotros consolidación), entre los modos de extinción de las obligaciones, aunque no de todas ellas sino de las de carácter dudoso o litigioso.

Para Luis De Gásperi ${ }^{16}$, quienes sostienen que la transacción es algo más que un modo de extinguir obligaciones tienen razón; pero no la tiene menos el Código de Vélez Sarsfield en cuanto la define como acto jurídico, que siendo una idea más general y más amplia que la de contrato, no impide que lo sea. Pero este autor considera tal vez un exceso de ambigüedad situarla como un acto jurídico, ya que la transacción reviste carácter netamente contractual y, por tanto, debe ocupar lugar entre las figuras de este género ${ }^{17}$. Lo mismo opina respecto de la novación, la que debería ubicarse entre los contratos extintivos, como la renuncia y la rescisión. Para el profesor De Gásperi, estos cambios convendrían a la economía de un código.

Vemos que tales consideraciones están provistas de buenos argumentos, ya que las concesiones recíprocas implican renuncias recíprocas de derechos, de donde se desprende su carácter sinalagmático: una de las partes es titular de un derecho dudoso o litigioso, y hace aban-

16 Luis De Gasperi. Op. cit, Tomo III, pp. 214 y ss.

17 Señala De Gásperi que si lo que se promete a cambio del derecho renunciado es una suma de dinero o una parte alícuota de las cosas litigiosas, el contrato será conmutativo. Si, en cambio, lo que se promete depende de un suceso fortuito, como una renta vitalicia, la transacción será aleatoria, porque el valor del derecho renunciado será incierto. 
dono o condonación parcial o total; la otra parte, quien se ve beneficiada por esta concesión, en virtud de la reciprocidad (o sinalagma) se obliga a cumplir una prestación determinada (que puede ser de dar, de hacer o de no hacer, o una combinación de éstas) en beneficio de la primera. Y como contrato sinalagmático, la obligatoriedad de cada prestación está en función del cumplimiento de la otra parte. Es así como la pretensión renunciada o condonada se encuentra expuesta a la exceptio non adimpleti contractus, es decir, subsiste en tanto la prestación prometida a cambio no sea cumplida.

El tratadista alemán Karl Larenz ${ }^{18}$ sostiene que la modificación de una relación obligatoria puede tener lugar también por medio de una transacción, ya que éste es un contrato por el cual se elimina, por medio de recíprocas concesiones, el litigio o la inseguridad (si bien solamente entre los interesados) acerca de una relación jurídica. La relación jurídica controvertida puede ser una relación obligatoria u otro tipo de relación jurídica (como por ejemplo un derecho real, o una pretensión de derecho sucesorio), siempre que los participantes en ella puedan disponer de la misma. Larenz, sin embargo, limita a aquellas transacciones que afectan a la relación obligacional; puede decirse que toda relación de deuda -e igualmente las pretensiones individuales derivadas de las mismas- puede ser objeto de transacción cuando acerca de ella se origine un litigio o una incertidumbre.

Expresa Larenz que mediante la transacción se crea nueva base de acción judicial; pero esto no significa extinción de la relación obligatoria preexistente y que una nueva venga a ocupar su lugar; por lo tanto, la transacción no persigue -salvo que las partes lo hayan estipulado expresamente- una sustitución de deuda (novación), sino que permite la coexistencia de la relación jurídica preexistente, regulándola de nuevo tan sólo en aspectos particulares, como por ejemplo, si las partes llegan a un acuerdo acerca de la cuantía discutida de un crédito existente entre ellas, caso en el cual subsisten los derechos de garantía que originariamente se establecieron; también subsisten ulteriormente, en cuanto sea posible, las excepciones que mediante la transacción no hayan quedado extinguidas.

18 Karl Larenz. Derecho de Obligaciones. Tomo I, Editorial Revista de Derecho Privado, Madrid, 1958, pp.136-139. 
Estima Larenz que la transacción pertenece a los «negocios declarativos", cuya finalidad es hacer segura e incontestable entre las partes una situación jurídica controvertida e insegura ${ }^{19}$.

Para este profesor alemán, la transacción aparece entonces como un contrato de modificación (se trata de una disposición conjunta de ambas partes sobre la relación obligatoria como un todo), con la finalidad de eliminar un litigio o una incertidumbre $y$, por tanto, desde un punto de vista formal es de carácter único o predominantemente «declarativo". Como contrato de modificación, actúa inmediatamente sobre la relación de deuda reformada, transformándola.

Larenz reconoce que el punto de vista que expone no es el de la doctrina dominante, la cual construye a la transacción estrictamente como un contrato obligatorio, que en forma alguna crea o incluye actos dispositivos. De ahí que no modifique la relación de deuda, sino que únicamente obligue a ello a las partes, las cuales han de efectuar "actos de ejecución" necesarios, por ejemplo, declaraciones de reconocimiento o renuncia. Ciertamente -a decir de Larenz-, estos negocios de ejecución, en cuanto no requieran forma alguna, podrán ser efectuados juntamente con la transacción, aunque sea lógico distinguirlos de la transacción propiamente dicha, que como tal, es sólo el «fundamento jurídico" de los negocios de disposición que de ella se separan o derivan y mediante los que se altera la relación jurídica. Larenz considera erró-

19 Puede ocurrir que el deudor reconozca el crédito discutido o incierto, ya en toda la cuantía afirmada por el acreedor o en otra inferior; el acreedor en el primer caso tal vez consienta en un aplazamiento del pago o aumente su contraprestación, pero en el segundo caso renunciará al excedente que en principio exigió (mediante el llamado "reconocimiento negativo"). Por lo tanto -opina Larenz-, la transacción contiene, en la mayoría de los casos, aunque no necesariamente, un reconocimiento por una de las partes o por ambas. En estos supuestos no se trata, por regla general, de un reconocimiento abstracto en el sentido del artículo $781^{\circ}$ del B.G.B., que tal vez tuviera un significado completamente novatorio, sino de un reconocimiento "causal": la deuda reconocida en transacción conserva su carácter anterior (por ejemplo, como débito del precio de la compraventa, o en concepto de mutuo). No surge ninguna nueva obligación ni junto a la existente ni en su lugar, pero cuando la deuda anterior no consistía en la cuantía ahora reconocida, el reconocimiento produce, no obstante lo dicho, efecto creador de la obligación. Y, a la inversa, si el acreedor se da por satisfecho en la transacción con una suma inferior a la efectivamente debida con anterioridad, hay en su reconocimiento ("negativo"), una renuncia y, por lo tanto, una disposición sobre su derecho. Por consiguiente, la alteración de la anterior relación obligatoria se verifica o por medio de ampliación o limitación del deber de prestación, por nueva fijación de su vencimiento, aceptación de deberes adicionales o renuncia de derechos accesorios (por ejemplo, al derecho de rescisión), variando su contenido originario por medio de la transacción. 
neo tal desdoblamiento de un negocio jurídico concebido como unitario por las partes. A su parecer, los partidarios de esta construcción olvidan que en el instituto del contrato de modificación tenemos la posibilidad de que las partes reformen directamente el contenido de la relación obligatoria y la reglamenten de nuevo, y cabalmente es éste también el resultado de la transacción.

Para Larenz, en suma, la transacción según su sentido rectamente entendido no solamente obliga a las partes a realizar la correspondiente modificación de la relación obligatoria por actos ulteriores, sino que esta modificación (en tanto los acuerdos adoptados se desvien efectivamente de la situación jurídica precedente) se produce además también directamente, pues la cantidad sobre la que las partes han transigido es la adeudada en adelante, aunque con anterioridad se debiere una mayor o menor.

Esta visión de la relación obligatoria como un todo y no fraccionadamente, sobre el cual se realiza la transacción también como un todo (así las disposiciones necesarias a tal fin-reconocimientos, remisiones, como la eventual aceptación de obligaciones accesorias, están contenidas también en la transacción, sin que para ello se requieran especiales "actos de ejecución»), es bastante interesante $y$, a nuestro entender, acertada, ya que de lo contrario cabrían impugnaciones parciales respecto de cada concesión, complicando aún más la relación jurídica, y esto, a todas luces, resultaría peligroso y no conduciría a esta figura a su razón de ser: solucionar conflictos armoniosamente.

Por su parte, Luis María Rezzónico ${ }^{20}$, refiriéndose a la naturaleza de la transacción, apunta que el artículo $832^{\circ}$ del Código Civil argentino señala que ella es un acto jurídico (porque tiene por objeto extinguir obligaciones), y bilateral (porque requiere concesiones recíprocas, es decir, concurso de voluntades). Pero este autor considera que su naturaleza es contractual, debido a que el propio Código Civil argentino la remite, en su artículo $833^{021}$, a los contratos. Además, siguiendo la

20 Luis María Rezzónico. Estudio de las Obligaciones en nuestro Derecho Civil, Volumen II, Ediciones De Palma, 1961, pp.1026-1027.

21 Artículo $833^{\circ}$ del Código Civil argentino.- "Son aplicables a las transacciones todas las disposiciones sobre contratos, respecto a la capacidad de contratar, al objeto, modo, forma, prueba y nulidad de los contratos, con las excepciones y modificaciones contenidas en este título." 
pauta de identificar la voluntad del legislador, para lo cual se remonta al Code, Rezzónico recuerda que Aubry y Rau, Baudry-Lacantinerie, entre otros, opinan que la transacción presenta los caracteres de un verdadero contrato, porque ella tiene por objeto regular los derechos de las partes.

En efecto, por las razones señaladas, podríamos concluir que la transacción es un contrato, ya que presenta características no sólo afines, sino identificables con éste: es consensual (se celebra mediante el acuerdo libre y voluntario de las partes); es bilateral, porque impone a las partes obligaciones recíprocas (sinalagmático); es a título oneroso (conmutativo o aleatorio, según los casos, por lo mismo que es sinalagmático); finalmente, es formal, puesto que su existencia depende de la observancia de la forma prescrita (ad solemnitatem).

Alterini, Ameal y López Cabana ${ }^{22}$, al referirse a la naturaleza jurídica de la transacción, expresan que si bien algunos autores, guiados por la definición de contrato que proporciona el artículo $1137^{\circ}$ del Código Civil argentino, la consideran como un contrato, otros, como Lafaille, opinan que es una convención, puesto que el contrato sólo sería la convención que "crea" obligaciones, de modo que no podría admitirse el carácter de contrato para la transacción que las extingue.

Los autores citados estiman que hasta donde la ley ilustra no cabe duda que estructuralmente la transacción es un acto jurídico bilateral; pero al buscar nuevas características a la figura, se hallan frente a la controversia acerca del concepto que se adopte para el contrato o para la convención, a fin de establecer si cabe en uno u otro grupo.

Refieren además que el problema ofrece dificultad ya que, a veces, la transacción, bajo el mismo ropaje del acto, no se limita a extinguir obligaciones, sino que vuelve a crearlas: se pueden extinguir obligaciones litigiosas o dudosas y, al mismo tiempo, crear obligaciones nuevas; caso en el cual podrá concurrir la naturaleza extintiva de la transacción con la naturaleza del contrato que pueda crearse, pero esa yuxtaposición no va a afectar en definitiva su verdadera esencia.

Como sabemos, siguiendo la línea conceptual de nuestro ordenamiento jurídico, dentro de la clasificación de los contratos de acuerdo a su función, estos pueden ser (a) constitutivos; (b) reguladores; (c)

22 Atilio Aníbal Alterini, Oscar José Ameal y Roberto M. López Cabana. Curso de Obligaciones, Tomo II, Abeledo Perrot, Buenos Aires, 1988, p.351. 
modificatorios; y (d) extintivos. La transacción, entonces, sería un contrato que estaría destinado a crear, regular, modificar o extinguir una relación jurídica de carácter patrimonial, naturaleza contractual que se deriva claramente de la lectura de los artículos $1302^{\circ}$ y $1351^{\circ}$ del Código Civil peruano. Constituye, además, la penúltima forma de extinción de las obligaciones que consigna el Código Civil de 1984.

Decimos que la transacción es un contrato creador, regulador, modificatorio o extintivo de obligaciones, por cuanto por esta vía las partes pueden solucionar sus diferencias, ya sea creando obligaciones distintas a las anteriormente contraídas, o regulando, modificando o extinguiendo las ya existentes, con el propósito de que con las precisiones que se efectúen se superen los problemas que amenacen conducir a un proceso judicial o a la continuación del mismo ${ }^{23}$.

\section{(b) La transacción como acto jurídico.}

Hay autores para quienes la transacción difiere en su naturaleza a la del contrato, debido a que, al igual que la novación y el pago, constituye un acto jurídico bilateral cuyo fin es la liberación. Es decir, se trata de una convención liberatoria y no de un contrato, ya que extingue obligaciones, en lugar de hacerlas contraer (que es el efecto propio de un contrato). De esta forma podría mantenerse para el contrato el carácter de fuente específica y principal de los derechos creditorios (para quienes sustentan la doctrina impugnada, la transacción forma parte de los contratos consensuales, a título oneroso y sinalagmáticos). Son de esta opinión los profesores Llerena, Colmo, Lafaille, Levenhagen y Boffi Boggero, entre otros.

Para Levenhagen ${ }^{24}$, si bien la naturaleza jurídica de la transacción encuentra en la doctrina y en el mismo Derecho internacional fuerte antagonismo, él considera que no obstante exigirse, para su existencia legítima, los mismos elementos imprescindibles que para los contratos

23 Sabemos que al decir "regular» un contrato no se está incluyendo o abarcando la idea de "modificarlo", puesto que la regulación carece del alcance que significa cambiar lo existente. La modificación implica pues un cambio en lo establecido por contrato entre las partes, pero debemos tener presente que este cambio no es total sino solamente parcial, y hasta cierto punto accesorio (pues no se altera lo sustancial).

24 Antonio José de Souza Levenhagen, Direito das Obrigą̧oes. Editora Atlas S.A., Sao Paulo, 1978, p. 164. 
(como la capacidad, objeto lícito, consentimiento válido, etc.), otras condiciones especiales deben integrarla, y entonces siendo un acto jurídico, no puede ser incluida entre las formas de contratos, pues éstos crean obligaciones, y la transacción apenas adecúa situaciones en cuanto a derechos ya existentes, ya creados ${ }^{25}$.

\section{(c) La transacción como medio extintivo de obligaciones.}

Como sabemos, la transacción no es regulada por el Código Civil peruano como un contrato o como un acto jurídico bilateral (en estricto), sino como una de las formas de extinción de las obligaciones, al igual que el Código Civil de 1936, el cual modificó en este punto al Código Civil de 1852, que la colocaba dentro de los contratos.

$\mathrm{El}$ argumento en que se basó la Comisión Reformadora del Código Civil de 1852 para optar por este cambio consideraba que al ser la transacción el acto jurídico en virtud del cual las partes, haciéndose concesiones recíprocas, extinguen obligaciones dudosas o litigiosas, entonces no se trata propiamente hablando de un contrato sino de un verdadero modo de extinguir obligaciones ${ }^{26}$. Es decir, la transacción es contrato en la medida que representa el resultado de la concordia de las voluntades, pero como es una convención que tiene por fin jurídico principal liquidar relaciones obligatorias preexistentes, es real y verdaderamente un medio de extinción de obligaciones. Se identificó, pues, como momento preponderante de la transacción al extintivo de las obligaciones, por lo que se consideró más adecuado ubicarla en ese rubro que en el de los contratos.

El doctor León Barandiarán compartía ese planteamiento ${ }^{27}$. Las razones esgrimidas por este tratadista enfocaban el tema desde el mismo ángulo, es decir, que si bien la transacción era abordada por la generalidad de los cuerpos legales como un contrato, había códigos

25 El Código Civil Brasileño no incluye a la transacción dentro del capítulo de los contratos, pero esto no obsta para que numerosos autores de ese país la califiquen como tal, no con el objeto de asegurar derechos o de extinguirlos, sino de consolidarlos, de defenderlos de la incertidumbre.

(26) Para esta Comisión, la transacción es inclusive un modo de extinción de los actos jurídicos en general, porque por ella se pueden extinguir derechos reales y derechos hereditarios.

(27) José León Barandiarán. Comentarios al Código Civil Peruano. Tomo II, Universidad Nacional Mayor de San Marcos, Lima, 1965, pp.555-556. 
(Austria, Argentina y Brasil) que ya la legislaban como un medio de extinguir las obligaciones, debido a que en realidad este último carácter es el resaltante en ella ${ }^{28}$. Y añadía que de acuerdo con ese criterio, se llegaba a la conclusión de que no podía reputarse a la transacción como un contrato stricto sensu, porque un contrato crea derechos y obligaciones. En cambio, la transacción sólo es declarativa de derechos.

La Comisión Revisora del Código Civil Peruano ${ }^{29}$, ubicando a la transacción como un medio de extinción de obligaciones, de la misma forma que el Código anterior (1936), siguió el siguiente razonamiento: primero consideró que la figura de la transacción presenta un doble aspecto; de un lado, es efectivamente un contrato destinado a poner fin a obligaciones dudosas o litigiosas, mediante concesiones recípro$\operatorname{cas}^{30}$. De otro lado, y aquí radica su base diferencial, la transacción es una forma de extinguir obligaciones, porque en múltiples casos prevalece el efecto extintivo de la transacción. Los argumentos, pues, son similares a los que impulsaron al legislador del Código de 1936 a colocar a la figura en este rubro. Se trata de focalizar su ámbito de aplicación. Así nos apartamos de las soluciones legislativas consagradas por los códigos civiles de Francia, Italia, Holanda, España, México, Uruguay, Chile, Colombia, Ecuador, Venezuela, Alemania y Obligaciones de Polonia.

Salvat ${ }^{31}$, al abordar el efecto extintivo de la transacción, señala que el mismo ha sido consagrado por el Código Civil argentino en los

28 Según el doctor León Barandiarán, si se considera a los contratos en su sentido más amplio, la transacción podría ser calificada como tal; pero en realidad, de esta forma se mengua la verdadera importancia de la transacción, que es, en el fondo, la búsqueda de la reconciliación entre las partes.

29 Comisión Revisora del Código Civil Peruano. Jack Bigio Chrem. "La Transacción. Exposición de Motivos del Código Civil". Separata Especial del diario oficial El Peruano. Lima, lunes 3 de diciembre de 1990, p.5.

30 Este razonamiento procede de una lógica limpia: la naturaleza contractual de la transacción se desprende de la definición que el artículo $1351^{\circ}$ del Código Civil establece del contrato. Entonces, siendo el contrato el acuerdo de dos partes para crear, regular, modificar o extinguir una relación jurídica patrimonial, la transacción se encuadra dentro de los alcances de esta definición. Este carácter se ve acentuado al haberse introducido el segundo párrafo del artículo $1302^{\circ}$ del Código Civil, según el cual se admite que la transacción pueda crear, regular o modificar relaciones diversas de las que son objeto de controversia.

31 Raymundo M. Salvat. Tratado de Derecho Civil Argentino. Tomo II, Edición actualizada con textos de doctrina, legislación y jurisprudencia por Enrique V. Galli, Tipográfica Editora Argentina, Buenos Aires, 1952, pp.249-250. 
siguientes términos: La transacción extingue los derechos y obligaciones que las partes hubiesen renunciado, y tiene para con ellas la autoridad de la cosa juzgada (artículo 850 ${ }^{\circ}$ ). Ergo, la transacción (tal cual resulta de los propios términos de la ley) produce como efecto fundamental y característico la extinción de los derechos y obligaciones que habían sido objeto de ella, es decir, de los derechos y obligaciones que las partes hubiesen entendido renunciar. En consecuencia, las partes no pueden en adelante exigirse nuevamente el cumplimiento de esos derechos y obligaciones, porque la transacción hace entre ellas las veces de una sentencia. De esta forma, en lugar de ventilar la cuestión en un juicio o de esperar la sentencia judicial en su caso, las partes se dictan voluntariamente su propia sentencia. La importancia de la transacción queda resaltada, ya que con ella la cuestión queda definitivamente resuelta, porque de otro modo las partes podrían desconocer este principio y pretender renovar la discusión de la cuestión transigida. En cambio, ahora se puede oponer una excepción de transacción (exceptio de litis por transactionem finitae), análoga a la cosa juzgada, pero que no se identifica con ella. En suma, Salvat apunta a que transigido un juicio, no procede en adelante que en él se dicte sentencia, puesto que concluida la cuestión desaparece el caso judicial.

En opinión nuestra, la transacción es un acto jurídico (qué duda cabe) puesto que constituye una manifestación de voluntad destinada a crear, regular, modificar o extinguir relaciones jurídicas. Asimismo, puede ser un contrato, por las mismas razones, por versar la transacción sobre relaciones jurídicas patrimoniales ${ }^{32}$. Ambos conceptos no son, pues, excluyentes sino complementarios.

Sin embargo, dado que esta figura supone una relación jurídica previa entre las partes, de la cual ha surgido algún asunto dudoso o litigioso, se trata que por medio de las concesiones recíprocas (que pueden desde luego crear, regular, modificar o extinguir relaciones diversas de aque-

32 En términos generales no se concibe una transacción que no verse sobre cuestiones de indole patrimonial, ya que los derechos u obligaciones extrapatrimoniales son intransigibles, particularmente los relativos al Derecho de Familia, pues estas áreas interesan al orden público. Pero en este último caso pueden darse excepciones, como la que prevé el sistema argentino en su artículo $843^{\circ}$, al permitir la transacción sobre cuestiones relativas a la validez o nulidad del matrimonio si tal transacción es en favor de su validez (la ley autoriza esta transacción con el fin de favorecer la institución matrimonial). En el Derecho Peruano, en cambio, sólo los derechos patrimoniales pueden ser objeto de transacción. 
llas que han constituido objeto de controversia), se extingan obligaciones mutuas entre las partes. En otras palabras, lo que destaca, el eje central de esta figura, reside en una extinción de obligaciones recíprocas, en una renuncia o concesión de cada una de las partes a su pretensión original. De esa forma se zanja una discrepancia surgida al interior de una relación jurídica obligacional. Por esta razón se le ubica como un medio extintivo de obligaciones, lo cual, repetimos, no implica negarle su condición jurídica de contrato, ni mucho menos de acto jurídico.

Asimismo, la transacción debe reunir, en cuanto a su objeto, las mismas condiciones que la ley prescribe para toda clase de contratos, iguales a las previstas para los actos jurídicos en general. De acuerdo con este criterio, la transacción debe contener, como requisito de validez (además del agente capaz y la observancia de la forma prescrita), un objeto que sea posible, física y jurídicamente, así como un fin lícito. En consecuencia, la transacción precisa tener como objeto bienes que se encuentren en el comercio o, en todo caso, que la ley no haya prohibido transigir sobre ellos y, finalmente, que tal objeto sea determinado, es decir, preciso y cierto.

\section{Asunto dudoso}

Luego de haber analizado los aspectos generales de la transacción, esto es, su concepto y naturaleza jurídica, es momento de ingresar al estudio de sus principales características. Como por medio de la transacción las partes deciden sobre algún asunto dudoso o litigioso suscitado en su relación jurídica, debemos tener en claro qué significa un asunto dudoso y qué un asunto litigioso.

Dudoso es aquello "que ofrece duda", "que tiene duda", "que es poco probable, que es inseguro o eventual"33. Duda es la "suspensión o indeterminación del ánimo entre dos juicios o dos decisiones, o bien acerca de un hecho o una noticia". También es una "cuestión que se propone para ventilarla o resolverla". Por último, dudar es "estar el ánimo perplejo y suspenso entre resoluciones y juicios contradictorios, sin decidirse por unos o por otros".

33 Real Academia de la Lengua Española. Op. cit., Tomo I, p. 518. 
Dudoso también es "lo incierto. De verdad no comprobada. De insegura falsedad. De acierto o frustración no probados. De éxito muy problemático. De solvencia remota. De interpretación equívoca." 34 .

Por su objeto, la transacción se circunscribe a las reglas generales de los actos jurídicos y de los contratos, y así las prestaciones obligatorias que nacen de la transacción deben reunir los requisitos de formalidad, licitud o libertad, determinación, posibilidad (física y jurídica) y también de valor patrimonial o económico (el objeto de la transacción son los derechos patrimoniales, y sólo por excepción algunas cuestiones de índole extrapatrimonial que no alteran el orden público). Solamente en cuanto a la determinación del derecho a que se renuncia (la concesión que cada parte debe hacer) ya hay una diferencia sustancial entre la transacción y los otros contratos, ya que si la determinación del objeto es la regla general de todo contrato (no obstante puede existir un cierto grado de indeterminación respecto de su cantidad), la incertidumbre del derecho sobre el que recae la transacción (res dubia) constituye la esencia de ésta.

Basta, en consecuencia, que el asunto sea dudoso, sin que sea necesariamente litigioso. De mantenerse la duda, no es difícil que devenga (o degenere) en un asunto litigioso. En efecto, puesto que la transacción puede recaer sobre derechos y obligaciones meramente dudosos, no hace falta que haya pleito pendiente, sino que se dé el elemento de incertidumbre en la relación jurídica de las partes. Entonces las partes, si así libremente lo desean, pueden prevenir el eventual litigio por medio de la transacción.

Ahora bien, consideramos que es claro que si en el supuesto de existir un fallo judicial quedaran o surgieran dudas acerca del valor de lo juzgado, o existiese insatisfacción por ambas partes respecto de su sentido, no habría razón para que no pudiera realizarse una transacción sobre el mismo asunto ya juzgado y sentenciado. Evidentemente, ello es factible en la medida en que esta transacción no perjudicara el derecho de terceros.

Para Salvat ${ }^{35}$, obligaciones dudosas son aquellas que las partes seria y sinceramente han considerado como tales. Entonces la palabra dudo-

34 Cfr. Guillermo Cabanellas. Op. cit. Tomo IIl, p. 340. Este mismo profesor señala que el término "duda" es una "Suspensión o indeterminación de la voluntad o del entendimiento entre varias decisiones o juicios, cuando no se halla estímulo o razón bastante para aceptar o 
sa hay que tomarla en un sentido subjetivo y no objetivo; es decir, referirse a la opinión y al sentimiento de las partes mismas que realizaron la transacción, no a la opinión que pudiera formarse sobre el asunto un juez, un abogado más o menos ilustrado o cualquier otra persona. Aun cuando en la opinión del juez o del abogado la eficacia de una obligación no pudiera, en lo más mínimo, parecer dudosa, si las partes la han considerado seriamente como tal, habría transacción. Esto, según Salvat, se explica en que por una parte, los jueces o tribunales no tienen la misión de pronunciarse sobre cuestiones abstractas, como sucedería si tuviesen que resolver sobre el valor legal de obligaciones cuya eficacia los interesados directamente y de común acuerdo estimaban dudosas; $y$, por otra, no obstante la mayor o menor seguridad de su derecho, a pesar de su absoluta seguridad, si se quiere, las partes, al determinarse a celebrar la transacción, han podido temer los errores de la justicia, los gastos que en mayor o menor escala quedan frecuentemente $\sin$ indemnizar, las molestias e incomodidades del juicio, la repercusión que éste podría tener sobre sus negocios, etc.

Relacionando en una secuencia lógica al elemento desacuerdo como generador de incertidumbre, Levenhagen ${ }^{36}$ considera que es de establecerse que la objeción sobre las relaciones jurídicas surge del desacuerdo entre las partes, y con ese desacuerdo aparece la incertidumbre en cuanto al derecho de cada una de ellas. Consecuentemente, viene la posibilidad de establecerse el litigio, la demanda judicial. Así, la transacción surge, entonces, como un remedio preventivo, para evitar el inicio de ese conflicto.

La controversia teórica respecto de la objetividad o subjetividad como elemento integrante básico constitutivo de la duda, es retomada por Alterini, Ameal y López Cabana ${ }^{37}$, quienes en relación a las obligaciones dudosas, opinan que su concepto es difícil de definir, ya que está controvertido si comprende sólo a aquellas obligaciones que "subjeriva-

asentir entre los objetos o conceptos opuestos o diferentes. Incertidumbre sobre la verdad de un hecho, noticia, proposición o aserto. Cuestión propuesta para discutirla o resolverla." (Ibid., pp. 339-340).

35 Raymundo M. Salvat, Op. cit., Tomo II, pp. 193-194.

36 Antonio José de Souza Levenhagen. Op. cit., p. 163.

37 Atilio Aníbal Alterini, Oscar José Ameal y Roberto M. López Cabana. Op. cit., Tomo II, p. 350 . 
mente" las partes tienen como tales, o si son dudosas cuando "objetivamente", y a través de la opinión de especialistas, pudieran parecerlo. Los profesores citados entienden que es suficiente que las partes consideren incierto su derecho para que exista transacción, sin necesidad de requerir opinión de los expertos.

De hecho no resulta, a nuestro criterio, crucial para que se pueda transigir, que la duda provenga de obligaciones que las partes subjetivamente consideren dudosas o si objetivamente han sido catalogadas de esa forma. La razón es muy simple: puede ser que haya un "subjetivismo" puro, o un "objetivismo" también puro, o inclusive una mezcla de ambos. Puede inclusive haber duda subjetiva sobre una duda objetiva, lo cual, si bien suena algo exagerado, en realidad no lo es (la esencia de la duda es precisamente la confusión respecto a una diversidad de aspectos). Y, en todo caso, los asuntos dudosos no son por lo general puros en cuanto a objetividad o subjetividad. Cada parte puede tener una opinión de algún connotado especialista, que no sean coincidentes y, de esa forma, existirían criterios "objetivos" distintos. De modo que, y en resumen, si las partes consideran que hay incertidumbre, provenga esta de donde provenga, y no se sienten satisfechas con tal incertidumbre, las puertas de la transacción están abiertas.

Llambías $^{38}$ expresa que la materia de la transacción son las obligaciones litigiosas o dudosas. Un acuerdo extintivo que recayese sobre obligaciones que no fueran litigiosas o dudosas, no sería una transacción porque la "res dubia" es de la esencia de esa figura. En efecto, la transacción es un negocio o acto jurídico de fijación, que tiende a hacer cierta, o a poner fuera de discusión, una situación determinada eliminando la incertidumbre de la relación; pudiendo ser esa incertidumbre, objetiva o subjetiva: la primera corresponde a las obligaciones litigiosas que son las que están sometidas a un pronunciamiento judicial; la segunda origina las obligaciones dudosas, es decir, las que las partes sinceramente han estimado como tales, aunque en verdad no lo fueran para un jurista especializado.

Nosotros consideramos que un asunto dudoso es aquel en el cual existe más de una interpretación que lleve a soluciones jurídicas distin-

38 Jorge Joaquín Lambías. Tratado de Derecho Civil, Tomo III. Abeledo Perrot, Buenos Aires, 1987, p. 76. 
tas y por lo cual podría suscitarse una controversia judicial o extrajudicial. Por tanto, el que un asunto sea dudoso no es obstáculo para que sea litigioso, ya que puede revestir ambas características.

Sin embargo, cabe precisar que para que se produzca una transacción no necesariamente tendremos que estar frente a un asunto estrictamente dudoso. Podría ocurrir que nos encontremos ante un asunto de meridiana claridad, en el cual se precisen con nitidez los derechos y obligaciones que surgen para cada parte, y que incluso estas últimas tengan la certeza de lo que consiste aquello a lo que se han obligado. Aquí, como se puede apreciar, entramos a la esfera de lo litigioso.

Para que se considere litigioso un asunto basta el hecho de una eventual negativa de una de las partes a cumplir con la ejecución de la prestación a la que se ha obligado, por más pueriles que sean sus argumentos o aun careciendo de ellos. Lo litigioso puede consistir simplemente en la apreciación o simple negativa del supuesto deudor. Creemos que aquí el término "dudoso" se confunde con "litigioso", ya que al primero habría que combinarlo con la expresión que le sigue en el artículo bajo comentario: "evitando el pleito que podría promoverse...". Dentro de un raciocinio lógico, si el deudor -aunque claramente tenga esta condición- rehusase efectuar el pago, el acreedor tendría que demandarlo judicialmente, y entonces estaríamos ante un asunto estrictamente litigioso (por más clara que fuera la posición del acreedor), el mismo que sería susceptible de transacción, en virtud de la expresión que utiliza el artículo $1302^{\circ}$ : "finalizando el (pleito) que está iniciado".

También podría ocurrir, debido a las más diversas razones, como por ejemplo un sorpresivo estado de insolvencia del deudor, que las partes se pusiesen de acuerdo para transigir respecto de una determinada obligación, concluyendo en una situación diversa de la originalmente pactada. En esto podría haber una gran arbitrariedad por parte del deudor; pero ¿cómo evitaríamos tal arbitrariedad y el subsiguiente litigio?. Y en un litigio -insistimos-, por más claro que él sea, siempre procede celebrar una transacción. Por ello las palabras "duda" y "litigio", para efectos de la transacción, están íntimamente vinculadas.

\section{Asunto litigioso.}

Dentro del término litigioso están comprendidos los asuntos que sean materia de una controversia judicial (litis) o de un arbitraje. 
Litigio es "pleito, altercación en juicio. Disputa, contienda.", y litigioso "... lo que está en pleito. Por extensión, dícese de lo que está en duda y se disputa. Propenso a mover pleitos y litigios." ${ }^{39}$.

Litigioso también es definido como "lo que constituye objeto de litigio o pleito. Lo disputado o controvertido en un juicio. De dudosa resolución y efectiva controversia. Propenso a suscitar litigios o causas.", y litis como "Pleito, causa, juicio, lite. Esta voz latina se conserva como vocablo jurídico incorporado a nuestra lengua." ${ }^{40}$. La doctrina es prácticamente unánime en considerar a las obligaciones litigiosas como las que son materia de juicio o pleito judicial. Sin embargo, en lo que no hay coincidencia es en cuanto a si el pleito o litigio debe ser ya una realidad o únicamente potencial.

Por ejemplo, Salvat ${ }^{41}$ señala que las obligaciones litigiosas son aquellas que constituyen materia de controversia o discusión judicial a su respecto, que estén sometidas a la decisión del tribunal, y que igualmente se ha considerado transacción sobre derechos litigiosos, la que pone fin a una demanda que habiendo sido iniciada, no estaba notificada y, por lo tanto, no existía todavía litis trabada. De igual forma, Alterini, Ameal y López Cabana ${ }^{42}$, al definir la finalidad de la transacción como el camino para extinguir obligaciones litigiosas o dudosas, indican que las obligaciones litigiosas son aquéllas materia de un juicio contradictorio, y que esperan ser dilucidadas por los tribunales. Cazeaux y Trigo Represas ${ }^{43}$ indican que obligación litigiosa es la que está sometida a juicio, y que "para verificar su existencia basta con constatar la materialidad del pleito en el cual sea objeto de controversia".

Cubides Camacho ${ }^{44}$ no distingue cuestiones dudosas de litigiosas, mencionando tan sólo a las litigiosas y basándose en las sentencias de la Corte Suprema de Justicia de Colombia (particularmente en la de

39 Real Academia de la Lengua Española. Op. cit., Tomo II, p. 838.

40 Guillermo Cabanellas. Op. cit., Tomo V, p. 220.

41 Raymundo M. Salvar. Op. cit., Tomo II, p. 193.

42 Arilio Aníbal Alterini, Oscar José Ameal y Roberto M. López Cabana. Op. cit., Tomo II, p. 350

43 Pedro N.Cazeaux y Félix A. Trigo Represas. Compendio de Derecho de las Obligaciones, Tomo II. Editorial Platense, La Plata, Argentina, 1986,p. 333.

44 Jorge Cubides Camacho. Obligaciones. Pontificia Universidad Javeriana, Tercera Edición, complementada y actualizada con la colaboración de Juanita Cubides Camacho, Bogotá, 1996, p. 394. 
fecha 6 de mayo de 1966), señala que la transacción tiene como elemento específico la existencia de una diferencia litigiosa, es decir un proceso pendiente o la perspectiva de un proceso. Carnelutti ${ }^{45}$ denomina litigio al conflicto de intereses calificado por la pretensión de uno de los interesados y por la resistencia del otro; enfoque exacto en el proceso civil como nudo del mismo, pero en su concepto se advierte la ausencia del planteamiento judicial, debido a que los conflictos de intereses extrajudiciales existen en mucho mayor número que los llevados ante la justicia, instancia última de muchos de aquellos otros.

A nuestro entender, no cabe restringir el alcance del concepto referido al "asunto litigioso" por razones de estricto (por no decir extremo) tecnicismo, ya que de lo que se trata es de enfocar a la figura de la transacción, contemplando principalmente su finalidad o ratio, y de esa forma establecer el alcance verdadero que facilite y no obstaculice su razón de ser. Por ello la propia norma refleja tal intención por parte del legislador, al señalar que el asunto sea litigioso (palabra por demás ambigua y amplia) y no que exista un litigio (que nítidamente presupone un juicio ya encaminado).

Para la existencia del litigio es necesario que al menos la demanda se haya interpuesto y que haya sido contestada, es decir que la litis se encuentre trabada. En el caso de la transacción esto no es necesario. Puede existir un pleito pendiente, o tan solo una demanda interpuesta, o inclusive que ningún paso se haya dado por las partes para iniciar proceso alguno, pero si el asunto pudiera ser materia de proceso ( $\mathrm{y}$ no meramente dudoso), ya encaja dentro del radio conceptual del asunto litigioso, como complemento a los asuntos meramente dudosos. De esa forma no queda ningún aspecto que produzca incertidumbre o malestar a las partes que las imposibilite para transigir.

Sabemos, en suma, que toda reclamación extrajudicial no configura litigio procesal. Aquí resulta útil la diferenciación entre asunto dudoso y asunto litigioso. La reclamación extrajudicial que no tenga posibilidades de ser interpuesta por la vía judicial constituye un asunto dudoso, en tanto que todas las demás (es decir, las reclamciones que pueden ser materia de litigio procesal) constituyen asuntos litigiosos. Asimismo, una vez planteada la demanda, si el demandado se allanase a ella,

45 Citado por Cabanellas (Guillermo Cabanellas. Op. cit., Tomo V, p. 220.) 
elimina el carácter contencioso del proceso. En este caso nunca se habría producido litigio, aunque hasta el momento del allanamiento sí habría habido un asunto litigioso.

En el caso de un litigio en trámite, si el demandado reconociese el derecho del demandante, ya no se puede considerar a la obligación como litigiosa (por lo que no cabría transacción), no obstante éste le hiciere alguna concesión sobre aspectos aledaños a tal derecho, como por ejemplo la forma de hacerlo efectivo o el importe de las costas y costos del proceso.

En suma, los derechos y/u obligaciones de las partes deben encontrarse en tela de juicio, ser inciertos, a fin de que se consideren litigiosos. Por ello es que tampoco puede considerarse litigiosa una obligación si se dictara sentencia y esta fuese consentida. En tal caso, ya están establecidos los derechos de las partes por el órgano administrador de justicia, por lo que cada uno sabe con certeza cuál es su derecho y, consecuentemente, tampoco cabría la transacción.

Sin embargo, en este último caso, de existir algún resquicio de incertidumbre de las partes respecto a un punto integrante de esta sentencia, nada obsta a que por medio de concesiones recíprocas realicen una transacción. Claro que se debe diferenciar los aspectos sustanciales de los periféricos. Si se trata de aspectos que no tienen que ver con el derecho controvertido per se, sino con la forma de pago o de venta o remate de los bienes del deudor vencido, no se puede ya hablar de transacción sino de acuerdo, organización o arreglo entre las partes.

Debemos reiterar, para finalizar este punto, que éstos pueden también no ser, en estricto, asuntos dudosos, ya que podría ser que se tratase de un asunto que a pesar de ser de meridiana claridad ha sido materia de una demanda tendenciosa.

En efecto, como en los juicios y en todo procedimiento no basta con tener la razón sino que también concurren otros elementos (probanza, urgencia, y hasta la suspicacia de que la autoridad se equivoque o simplemente que no sea imparcial), entonces podría ocurrir que a pesar de tener la razón un litigante, la sentencia que constituya cosa juzgada vaya contra sus intereses. Todo procedimiento judicial o arbitral es, por esencia, aleatorio. Esta situación de aleatoriedad no convierte en dudoso al asunto en sí, sino a su devenir; dudoso por el resultado del proceso. Por ello es que de alguna forma el elemento duda se encuentra en cualquier caso que amerite una transacción, aún cuando sea 
meramente litigioso. La duda (cuya manifestación es la indeseable sensación de incertidumbre) respecto de un asunto o del posible resultado de un proceso tiene como opción altamente viable a la transacción.

\section{Concesiones recíprocas}

\section{¿Qué significa realizar concesiones recíprocas?}

Realizar una concesión es ceder en una posición ideológica, dar u otorgar alguna cosa o derecho, declinar respecto de una actitud adoptada, o asentir en una manifestación ajena.

Una concesión es un "punto de la reclamación contraria que se acepta en una transacción o negociación" ${ }^{46}$.

Vemos que conceder es ceder, lo cual implica desde luego una posición antagónica previa. Cuando se cede es que se tenía una postura determinada que se decide relajar u otorgar al contrincante en aras de la convivencia pacífica o de algún beneficio ulterior. Se concede (o se cede) un derecho sobre algún bien. Así, Alberto puede ceder a Mercedes una porción adicional respecto de un bien hereditario que a él le correspondía (o consideraba que le correspondía). También respecto a alguna materia dudosa (de ahí la expresión "le concedo el beneficio de la duda"). Conceder también puede significar otorgar una gracia que está en manos del que dispone de ella (el César podía conceder la vida a los luchadores o gladiadores que habían ofrecido una buena lucha).

Ahora deseamos referirnos al significado de reciprocidad. El término recíproco significa "Igual en la correspondencia de uno a otro" ${ }^{47}$, y también "Mutuo. Igual en el trato o correspondencia. Con prestaciones equivalentes para las diversas partes. Bilateral." ${ }^{48}$; en tanto reciprocidad significa "Correspondencia mutua de una persona o cosa con otra" 49 , así como "Igualdad en el trato. Correspondencia en las relaciones. Acción y reacción mutuas y acordes en sentido de coincidencia o discrepancia, de armonía o conflicto ${ }^{50}$.

46 Guillermo Cabanellas. Op. cit., Tomo II, p. 253.

47 Real Academia de la Lengua Española, Op. cit., Tomo II, p. 1153.

48 Guillermo Cabanellas. Op. cit., Tomo VII, p. 38.

49 Real Academia de la Lengua Española, Op. cit., Tomo II, p. 1153.

50 Guillermo Cabanellas. Op. cit., Tomo VII, p. 38. 
Reciprocidad implica bilateralidad, sinalagma. Esta puede darse en obligaciones con prestaciones de dar, de hacer y de no hacer ("do ut des", "do ut facias", "facio ut des" y "facio ut facias", a las que habría que agregar las de no hacer en cada supuesto: "doy para que no hagas" y "hago para que no hagas"). El nivel de equivalencia está en función de la valoración que las partes hagan de las prestaciones, como en cualquier contrato.

En lo que respecta al requisito de que la transacción debe implicar concesiones recíprocas, esta situación significa que necesariamente las partes que celebran dicha transacción tienen que ceder en algo respecto de sus posiciones de origen, para finalmente llegar a un acuerdo que haga que ellas, si bien no hubieran llegado a un acuerdo que satisfaga sus expectativas originales, sí hubieran llegado a un acuerdo cercano a dichas posiciones. Decimos que debe ser cercano, ya que es precisamente esta cercanía la que les habrá permitido ceder en algo y todavía encontrarse satisfechos con lo acordado.

Constituye elemento fundamental de la transacción el hecho de que ambas partes se hagan concesiones recíprocas. Esto quiere decir que las dos cedan sobre sus pretensiones respectivas en la parte dudosa o litigiosa. Las concesiones recíprocas son la solución al impase. Reiteramos que reciprocidad no implica equivalencia más que en términos relativos.

La valoración de las concesiones es realizada por las propias partes. Por otro lado, la ley no exige que las concesiones mutuas sean de igual valor; la exigencia para que haya lugar a una transacción es que existan concesiones recíprocas, no siendo relevante el que una de las partes transija (o ceda) más o menos que la otra. Basta que cada una lo haga voluntaria y espontáneamente con la finalidad de dar por terminado el conflicto y evitar el litigio que podría promoverse o terminar el ya iniciado. Entonces una de las partes puede renunciar a la totalidad de su pretensión (respecto del asunto dudoso o litigioso), y la otra tan sólo abandonar en forma limitada sus derechos. También puede darse que una de las partes abandone o renuncie a mucho para recibir poco (Transactionibus receptum est ut pro modico magna amittamus), pero esto es semejante a realizar una compraventa de un bien a un precio inferior al del mercado; se trata de decisiones voluntarias de partes contratantes. Y en el caso de la transacción esto es aún más complejo al existir una tensión producida por la incertidumbre, por lo que no se debe evaluar los valores pecuniarios aisladamente, sino dentro de un conflicto que se busca eliminar para restablecer la armonía y la concordia. 
Un ejemplo ideal de transacción, en el cual ambas partes habrían cedido por igual, sería aquel en donde las dos partes consideren, una que debe a la otra 6,000 nuevos soles, mientras que el acreedor considere que su deudor le debe 10,000 nuevos soles; y que antes de promover un procedimiento judicial, ambas lleguen al acuerdo y pago de la cantidad de 8,000 nuevos soles. En el ejemplo que acabamos de señalar, la cantidad objeto de transacción sería exactamente la media proporcional entre las cantidades que sostenían como ciertas cada una de las partes ${ }^{51}$.

Pero soluciones como estas no siempre son factibles o viables, ya que por las más diversas circunstancias será casi imposible que las partes estén en igualdad de posiciones y condiciones para discutir la materia de la futura transacción. Por ello es frecuente que en las negociaciones una parte ceda más que la otra (además de la valoración subjetiva que cada una asigne a su "sacrificio"). Lo que busca la ley es que ambas cedan en sus posiciones originarias. Si así fuese, independientemente de lo que ceda cada una, habrá transacción, puesto que lo que conduce a las personas a transigir proviene de una suerte de desconfianza respecto de la justicia proporcionada por los tribunales de Justicia, fundamentalmente en relación a los dos aspectos que ya hemos mencionado; por un lado, la demora, y por otro la incertidumbre sobre la interpretación de sus derechos. Es por evitar exponerse a un proceso oneroso, interminable y cuyo resultado es aleatorio, que una de las partes puede llegar a optar por conceder más de lo inicialmente previsto, y termina consintiendo en una renuncia mayor a la de su adversario.

Pero si solo una de las partes cediese en sus supuestos derechos ${ }^{52}$, no se trataría de una transacción, sino de un acto de liberalidad (tal vez de una donación o una condonación). Por otra parte, desde la óptica del único que cede, éste no llegaría a sentirse satisfecho, sino forzado a ceder, por lo que la insatisfacción no se habría resuelto, cosa que en una transacción sí ocurre porque ambas partes "reciben" como contraprestación la renuncia (concesión) de la otra. Sabemos que el

51 También se da en el típico y cotidiano caso de la hora para un encuentro o reunión: "voy a las 6:00 p.m.", frente a "ven a las 5:00 p.m.", acordar que la reunión se inicie a las 5:30 p.m. Es el principio salomónico.

52 Decimos "supuestos" pues el asunto es dudoso o litigioso. 
objeto de la transacción se orienta a transformar un estado jurídico inseguro en otro seguro y a obtener estos resultados por el intercambio de prestaciones que pueden ser o no equivalentes.

Ahora bien, puesto que transigir significa ceder, y ceder implica renunciar, debemos reiterar que no todos los derechos pueden ser objeto de transacción. Así, los derechos irrenunciables son incompensables. Por ello es que para nuestro Derecho la transacción debe versar necesariamente sobre derechos patrimoniales.

\section{La transacción como un acto complejo.}

La transacción, como señalamos al iniciar este análisis, es un acto que puede ser altamente complejo. El código civil establece que con las concesiones recíprocas también se pueden crear, regular, modificar o extinguir relaciones diversas de aquellas que han constituido objeto de controversia entre las partes.

Es evidente que cuando se realizan negociaciones para llegar a una transacción lo que las partes buscan es concluir con el problema suscitado; y si desean esto de modo vehemente no será raro que recurran a cualquier medio alternativo o complementario para obtener tal propósito. Entonces podría ocurrir que para llegar al acuerdo sobre el o los puntos controvertidos, una parte ofrezca o acepte ofrecer a la otra la realización de alguna prestación complementaria (que puede ser de dar, de hacer o de no hacer) a lo que es materia de discusión, y de esta forma la otra parte vea satisfechas sus expectativas y a la vez esté dispuesta a llegar a un acuerdo. En tal virtud, la ley deja abierta esta posibilidad, pudiendo así la transacción comprender asuntos distintos a los que constituían materia de la controversia original. Tales asuntos distintos podrán ser creados, modificados, regulados o extinguidos, ya que las partes tendrán la más amplia libertad de configuración interna respecto de la transacción que deseen celebrar.

Vemos que la transacción puede constituir un acto sumamente simple, pero también uno extremadamente complejo en el que se entremezclen diversas figuras jurídicas típicas y atípicas.

La posibilidad de que con la transacción se creen, regulen, modifiquen o extingan relaciones jurídicas diversas de aquéllas que han consti- 
tuido objeto de la controversia entre las partes, significa que la ley les otorga la suficiente flexibilidad requerida a fin de que solucionen sus controversias o problemas entre ellas mismas. El Derecho es consciente de que con frecuencia las partes no van a poder llegar a solucionar sus problemas recurriendo únicamente a aquellos elementos que constituyen objeto de controversia, pues el margen de acción podría resultar reducido. Entonces, dentro de una transacción podemos encontrar diversas figuras extintivas, como la compensación, la novación, la condonación, todo ello, evidentemente, dentro de un marco contractual que a su vez crea nuevas obligaciones. La transacción engloba, pues, una serie de actos, siendo ante todo un contrato cuyo objeto es solucionar dificultades que han emergido de una relación jurídica obligacional preexistente, es decir, extinguir (por medio de las concesiones recíprocas) las obligaciones materia de conflicto.

Ahora bien, si a través de un acto transaccional las partes no sólo extinguieran obligaciones, sino que crearan otras nuevas, es natural que cualquier controversia nacida con respecto a estas obligaciones constituirá materia susceptible de reclamo o de eventual discusión en los tribunales de Justicia. Ciertamente podrían producirse incumplimientos de las obligaciones que las partes hayan asumido ejecutar en el futuro como parte del acuerdo transaccional, y por ende podría resolverse este contrato por inejecución de obligaciones, vale decir que le serían aplicables las normas generales de resolución por incumplimiento contenidas en el Código Civil respecto al contrato con prestaciones recíprocas, con la incomprensible excepción prevista para las transacciones judiciales por el artículo $337^{\circ}$ del Código Procesal Civil, que impide al perjudicado con el incumplimiento de la transacción solicitar la resolución de ésta.

\section{Capacidad.}

¿Quién puede transigir? Ciertamente solo aquel que puede disponer de los objetos materia de transacción. Entonces, la persona que tiene plena capacidad sobre los bienes comprendidos en la transacción es quien está en aptitud de realizar los actos de disposición correspondientes. 
Esta capacidad se traduce en la facultad para desprenderse, gravar, limitar o modificar los derechos comprendidos en la transacción ${ }^{53}$.

Ya hemos manifestado que la transacción es un acto complejo, pues comprende concesiones recíprocas de diversa y variada índole (en cada una de las cuales puede haber un desprendimiento, una renuncia, o una limitación a un derecho), por lo que se deberá analizar la capacidad en función del acto en sí mismo, así como en torno a los bienes que la transacción comprende respecto a los cuales se harán concesiones (es decir, enajenaciones). Entonces la capacidad de disposición de los bienes comprendidos en la transacción se refiere a cada uno de ellos en forma individual y autónoma, siendo la transacción ineficaz si una de las partes no podía disponer de alguno de dichos bienes.

De esta forma, si por ejemplo la transacción comprendiese un pleito, un inmueble y derechos patrimoniales sobre alguna creación artística, cada bien deberá ser disponible en forma individual y a su vez global (o en su conjunto) por la parte que lo ceda. Esto último opera así porque la transacción es indivisible, salvo pacto en contrario (artículo $1310^{\circ}$ del Código Civil peruano de 1984).

\section{Clases de transacción.}

(a) Según si se realiza dentro o fuera del litigio.

\section{(a.1)Transacción judicial.}

Se tratará de una transacción judicial en el caso que se llegue a un acuerdo para poner fin a un litigio (que, como hemos visto, podría ser judicial o arbitral) ya existente.

\section{(a.2) Transacción extrajudicial.}

Contrario sensu, será cuando se produzca respecto de un asunto que no es materia de una controversia judicial o arbitral, evitando que se promueva un litigio sobre el asunto acerca del cual se transige.

53 No debemos confundir este tipo de capacidad con la de goce y ejercicio de los incapaces. En cuanto a la posibilidad de los incapaces de realizar transacciones, éstos y los ausentes podrán transigir por medio de sus representantes, con aprobación del juez (artículo $1307^{\circ} \mathrm{del}$ Código Civil peruano). 
(b) Según su magnitud.

(b.1)Transacción total.

Es muy extendida la noción de que la transacción tiene que ser total, entendiendo por esto último que las partes con la transacción solucionan íntegramente la controversia que les atañe.

\section{(b.2) Transacción parcial.}

Decíamos que la generalidad de autores y de ejemplos que se citan en doctrina llevan implícita la existencia de una transacción total, pues en ningún momento se menciona la posibilidad de que con posterioridad a haberse celebrado el acto transaccional subsista alguno de los problemas de origen.

Sin embargo, el tema de la transacción parcial no puede ser apreciado de manera expresa en ninguna de las normas que sobre el particular contiene el Código Civil peruano (artículos $1302^{\circ}$ a $1312^{\circ}$ ). Ello no significa, empero, que la figura no resulte factible en los planos teórico y práctico, ya que entendemos por transacción parcial a aquella que pone término a alguno o a algunos de los aspectos del problema o controversia existente entre las partes.

Por consiguiente, nada impide que las complejas relaciones obligacionales en que se encuentran involucradas las partes, se solucionen, vía transacción, parcialmente, quedando las no resueltas sujetas a decisiones jurisdiccionales o arbitrales $o$, inclusive, a futuras negociaciones de las partes.

Y ello obedece, como lo hemos manifestado en forma reiterada, a que al Derecho y a la sociedad en su conjunto les interesa que en su seno exista la menor cantidad de problemas o conflictos entre las partes, propiciando una vida armónica.

Claro está que lo ideal para el Derecho sería que las partes solucionaran la integridad de los temas controvertidos, pero igualmente a la sociedad le interesa que las partes pongan fin a sus problemas (aunque sea de manera parcial), frente a la posibilidad de que dichos problemas subsistan en toda su magnitud.

(c) Transacción meramente extintiva de obligaciones o como acto complejo. 
(c.1) La transacción como acto meramente extintivo de obligaciones.

La transacción podría circunscribirse a ser un acto exclusivamente extintivo de obligaciones, por el que las partes pongan fin a su controversia, sin dar nacimiento a ninguna otra relación jurídica. En este caso la transacción sería un típico medio extintivo de obligaciones.

\section{(c.2) La transacción como acto complejo.}

Pero, como también ha sido expresado, la transacción puede implicar la creación, regulación, modificación o extinción de nuevas obligaciones o de obligaciones distintas a la materia de controversia. En la medida que del acto transaccional se deduzca la creación de nuevas obligaciones, estaremos en presencia de una transacción no solo extintiva, sino que representará un acto complejo.

(d) Transacción derivada de concesiones recíprocas, en estricto, y transacción para cuyo acuerdo las partes se sirven de la suerte.

(d.1) Transacción derivada de concesiones recíprocas, en estricto.

Este caso se refiere a la transacción propiamente dicha.

(d.2) Transacción para cuyo acuerdo las partes se sirven de la suerte.

Conforme a lo dispuesto por el artículo $1311^{\circ}$ del Código Civil, cuando las partes se sirven de la suerte para dirimir cuestiones, ello produce los efectos de la transacción y le son aplicables las reglas del respectivo Título del Código Civil.

Esto significa que podría darse el caso de una transacción en la cual las partes no lleguen al acuerdo transaccional como fruto de una negociación -que implica un ceder voluntario y recíproco en cuanto a las pretensiones de origen-. Aquí las concesiones recíprocas estarían sometidas a opciones que la suerte o el azar dirimirá. Puede ocurrir, en efecto, que las partes tengan más de una alternativa de solución al conflicto, y no lleguen a ponerse de acuerdo en cuanto a la decisión de cuál es la más beneficiosa. En este caso, la suerte puede jugar un papel de- 
cisivo. Este tipo de transacción implica concesiones recíprocas, mas no en su sentido estricto, pero no deja de ser transacción, en la medida en que existe de por medio la concesión de ambas partes, así como el acuerdo de recurrir al mecanismo de la suerte para solucionar sus conflictos.

\section{Interpretación restrictiva.}

No se puede entender que las partes hayan transigido sobre otras cuestiones que las por ellas previstas, por lo que no caben interpretaciones extensivas o que vayan más allá de lo expresamente establecido por las partes. Esta es una de las razones por las que se exije que ella conste por escrito, bajo sanción de nulidad.

Es de interés señalar lo dispuesto por el artículo $835^{\circ}$ del Código Civil argentino, norma que expresamente establece que "las transacciones deben interpretarse restrictivamente. No reglan sino las diferencias respecto de las cuales los contratantes han tenido en realidad intención de transigir, sea que esta intención resulte explícitamente de los términos de que se han servido, sea que se reconozca como una consecuencia necesaria de lo que se halle expreso".

La finalidad de este dispositivo argentino es dirimir las controversias que se pudieran suscitar por causa de dudas posteriores a la transacción y que sean relativas a su extensión y objeto. Quiere decir que la transacción no sólo elimina las dudas y divergencias actuales respecto al asunto dudoso o litigioso entre las partes, sino también las que puedan aparecer en el futuro (siempre que sean por la misma razón, es decir, las relativas a su objeto), por lo que las renuncias o concesiones recíprocas a todos sus derechos, acciones y pretensiones, son de carácter extensivo hacia el futuro. Ergo, la regla según la cual la transacción es de strictissimi iuris se circunscribe a su objeto. La transacción implica una renuncia recíproca, y toda renuncia es de interpretación estricta o restrictiva. Y precisamente debido a que es de interpretación restrictiva, la transacción extingue exclusivamente los derechos dudosos o litigiosos que según la intención de las partes estén comprendidos en ella. Asimismo, la transacción no beneficia ni perjudica a los terceros interesados que no intervinieron en ella. 
Aunque en el Código Civil peruano de 1984 no existen similares preceptos que aquellos contenidos en el Código Civil argentino respecto de la interpretación restrictiva de los actos que impliquen renuncia de derechos, no cabe la menor duda respecto a que los principios que inspiran este parecer son también aplicables al Derecho peruano, en la medida que debe tenerse muy en cuenta el contenido literal y el espíritu del acto transaccional, pues se entiende que debe quedar claro el alcance de aquellos derechos sobre los cuales las partes se están poniendo de acuerdo en sus respectivas concesiones recíprocas. Concesiones son cesiones y, por tanto, renuncias, y éstas jamás pueden interpretarse un milímetro más allá de lo nítidamente expresado por las partes.

Finalmente, por tener la transacción carácter de cosa juzgada, es obvio que, al igual que en un juicio, en el que el juez únicamente puede resolver en base a lo expresamente señalado (y demostrado) por las partes, y no interpretando a su libre albedrío, dicha institución debe estar sujeta al mismo criterio.

\section{Valor de cosa juzgada.}

El artículo $1302^{\circ}$ del Código Civil peruano de 1984, en su último párrafo, establece que la transacción tiene valor de cosa juzgada. Esta, como sabemos, constituye lo resuelto por sentencia firme en última instancia, en juicio contradictorio, ante un juez o tribunal, y contra la cual ya no se admite recurso alguno. Por ello, la cosa juzgada se eleva al nivel de las verdades, adquiere la categoría de Derecho puro y no cabe contradecirla.

La Comisión Revisora del Código Civil de 1936 se inspiró en el cuerpo legal argentino respecto de este tema. Al establecer que la transacción tuviera el valor de cosa juzgada y que, por razón de ello, no se permitiese revivir la controversia sobre los derechos anteriores a la transacción (cuya discusión le dio origen), dejaron en claro que esto era sin perjuicio de que la parte transigente perjudicada con el incumplimiento de la otra, pudiese solicitar la resolución del contrato, judicial o extrajudicialmente (según lo dispuesto en los artículos $1428^{\circ}, 1429^{\circ}$ y $1430^{\circ}$ del Código Civil), pues la transacción no es otra cosa que un contrato con prestaciones recíprocas. 
"Esta situación puede originarse en el caso que la transacción sea creativa de relaciones jurídicas diversas de las controvertidas. Tal hipótesis puede ocurrir cuando en un litigio sobre cumplimiento de contrato, el comitente y el contratista de una obra, ponen fin al pleito por transacción y, además, mediante ésta, las partes acuerdan llevar a cabo una nueva operación comercial, bajo la forma de compraventa de cosa futura. Es indudable, pues, que en esa eventualidad, de acuerdo al párrafo tercero del precepto, tienen valor de cosa juzgada la relación litigiosa extinguida y la creada por la transacción. Sin embargo, se permite que la parte que resulte perjudicada por el incumplimiento de la otra (el comprador de un bien futuro por falta de entrega de este en el plazo estipulado), solicite la resolución de la transacción." ${ }^{54}$.

A pesar de que la moderna doctrina es contraria a la asimilación entre la cosa juzgada y la transacción, pues las distinguen aspectos esenciales, como veremos, si esta última detenta dos condiciones fundamentales, entonces la transacción sí tendrá autoridad de cosa juzgada para las partes y para sus sucesores, y la excepción de transacción podría proceder. Estas dos condiciones (que se derivan de una de las características de la transacción, que es su interpretación restrictiva) son la identidad de personas e identidad de objeto, es decir, que la cuestión se plantee entre las mismas personas (actuando en la misma calidad), y que la nueva cuestión sea la misma que había sido transigida. Existiendo estos dos requisitos, la calidad de cosa juzgada se puede oponer, ya que a través de la transacción las partes sustituyeron la sentencia que el juez hubiese tenido que dictar, extinguiendo su jurisdicción.

Las diferencias entre la cosa juzgada y la transacción, que han suscitado más de una acalorada discusión en doctrina, se podrían resumir de la siguiente forma ${ }^{55}: 1^{\circ}$ las sentencias que deciden diversas cuestiones pueden ser modificadas en parte y subsistir por el resto, al paso de la transacción, por ser indivisible, como está dispuesto por el artículo $834^{\circ}$ del Código Civil argentino, anulada que sea en parte, queda anulada en el todo; $2^{\circ}$ sus formas son distintas; $3^{\circ}$ las sentencias sólo

54 Comision Revisora del Código Civil Peruano. Jack Bigio Chrem. Op. cit., p. 8.

55 Luis De Gasperi. Op. cit., Tomo III, pp. 232-234. 
pueden ser dictadas cuando se da una controversia ya nacida, mientras que la transacción puede ajustarse para precaver un eventual litigio; $4^{\circ}$ las sentencias no pueden ser atacadas por vicio del consentimiento, al paso que la transacción puede ser anulada por estas causas; $5^{\circ}$ la transacción es atacable por acción de nulidad y las sentencias sólo por los recursos instituidos por el procedimiento.

Salvat ${ }^{56}$ considera que para explicar el efecto extintivo de la transacción se ha recurrido en doctrina a la idea expresamente enunciada en la parte final del artículo $850^{\circ}$ del Código Civil argentino, de que la transacción tiene entre las partes la autoridad de la cosa juzgada, idea cuyo origen se hace remontar al Derecho romano, del cual ha pasado al Código Civil francés y, por intermedio de éste, a los numerosos códigos modernos que se han inspirado en él. Agrega Salvat que en apoyo de esta idea puede invocarse un doble argumento: $1^{\circ}$ que la transacción lo mismo que la sentencia, concluye definitivamente la cuestión; $2^{\circ}$ que la transacción no puede intervenir sino para solucionar cuestiones dudosas o litigiosas, de manera que si bien es cierto que ella tiene su fuente en la libre voluntad de las partes, también lo es que esta voluntad sólo puede ejercerse cuando hay de por medio una cuestión dudosa o litigiosa; pero la tendencia general de la doctrina moderna es contraria a la asimilación entre la transacción y la cosa juzgada, que los mismos autores que la defienden reconocen ser demasiado absoluta. Estima Salvat que pueden, en efecto, invocarse en contra de ella los siguientes argumentos:

a) Desde luego, bien examinado el texto romano que ha servido de origen a esa doctrina, puede preguntarse si ese texto ha querido establecer un principio general o si más bien se ha tratado de justificar la solución del caso particular sometido a la decisión de los emperadores;

b) En segundo lugar, el efecto extintivo de la transacción y las diversas consecuencias prácticas derivadas de él pueden explicarse, sin hacer intervenir para nada la idea de cosa juzgada, por los principios del derecho de los contratos: la transacción tiene fuerza de ley entre las partes, lo mismo que cualquier otro contrato; y es lógico entonces que siendo voluntad de las partes poner fin a las cuestiones transigidas, ellas no pueden ser discutidas de nuevo;

56 Raymundo M. Salvat. Op. cit., Tomo II, pp. 251-252. 
c) Por último, existen entre las transacciones y las sentencias judiciales las siguientes diferencias: $1^{\circ}$ las formas son diferentes; $2^{\circ}$ las sentencias recaen siempre sobre un juicio trabado, la transacción puede celebrarse, sea sobre una cuestión litigiosa, sea sobre una cuestión simplemente dudosa; $3^{\circ}$ las transacciones pueden ser atacadas por adolecer de vicios de la voluntad, las sentencias no; $4^{\circ}$ la transacción puede ser atacada por medio de una acción de nulidad, contra las sentencias sólo cabe los recursos que las leyes de procedimiento prescriben; $5^{\circ}$ las transacciones son indivisibles, $y$, por consiguiente, al menos en principio, deben ser mantenidas o anuladas en el todo; las sentencias, por el contrario, pueden ser anuladas sólo en parte.

Esto quiere decir que la transacción no permite la revisión judicial (pues podría ser -de quererlo las dos partes- extrajudicial) del asunto sobre el cual se ha transigido.

Debe señalarse que la transacción judicial se puede efectuar en cualquier momento del proceso. Incluso, hayan sido ya expedidas alguna o algunas sentencias, siempre y cuando éstas no tengan carácter de cosa juzgada, vale decir, que se hayan interpuesto contra ellas los recursos impugnatorios respectivos, o que la ley franquee su interposición y que los plazos para tal efecto no hayan vencido.

Por nuestra parte, consideramos necesario dar una adecuada interpretación al texto del artículo $1302^{\circ}$, in fine, bajo comentario. Al decirse que la transacción tiene valor de cosa juzgada y al decir nosotros que lo pactado en ella es irrevisable, nos estamos refiriendo, naturalmente, al caso en el cual a través de la transacción se haya puesto término o se haya dado claridad solamente a una situación jurídica dudosa o litigiosa.

Pero, como hemos visto, cabría también la posibilidad de que la transacción comprenda relaciones diversas a aquellas que han constituido objeto de controversia entre las partes, y que a través de la transacción se hayan creado, regulado, modificado o extinguido estas relaciones distintas.

En tal sentido, si se hubiera incluido en la transacción otros asuntos, y a través de la transacción las partes se hubiesen comprometido a la ejecución de determinadas obligaciones, y éstas se incumplen, cabría la duda de si debería plantearse una acción judicial o si dicho cumplimiento sería exigible en vía de ejecución de sentencia. Por nuestra parte, 
creemos que el último de los anotados sería el camino concreto. No creemos que el sentido del artículo $1302^{\circ}$ sea que el acreedor deba promover un nuevo juicio.

Sería el caso en el cual, por ejemplo, a lo que se ponga término, fuese a una discusión o controversia acerca de la compraventa de un departamento o el pago de su precio en dinero; y que por virtud de la transacción una de las partes se comprometa a entregar a la otra un vehículo; y que la entrega de dicho vehículo no se produzca (se inejecute la obligación) o que habiéndose producido, no llegue a satisfacer a la otra parte, por tener vicios ocultos (por sólo citar un ejemplo de lo que podría ocurrir). En este caso, lo lógico y eficiente sería exigir el cumplimiento vía ejecución de sentencia, y no tener que promover un juicio.

Refuerzan los argumentos en el sentido de que la transacción no tiene valor de cosa juzgada, aquellos que facultan la anulación de la misma. En tal sentido, la doctrina considera que la transacción puede ser anulada por presentar algún vicio de la voluntad.

Independientemente de las consideraciones generales antes señaladas respecto a la relatividad del principio de cosa juzgada en sede de transacción, deseamos efectuar un análisis pormenorizado de la materia dentro del ámbito de nuestra legislación civil. En este sentido, debemos afirmar que no hay lugar al carácter de cosa juzgada en la transacción en una serie muy numerosa de supuestos, dentro de los cuales podemos mencionar los siguientes:

(1)Anulación de la transacción por incapacidad relativa del agente.

(2)Anulación de la transacción por vicio de error sobre la propia esencia del objeto del acto.

(3) Anulación de la transacción por vicio resultante de error esencial sobre una cualidad sobre el objeto del acto.

(4)Anulación de la transacción por vicio resultante de error esencial sobre las cualidades personales de la contraparte.

(5)Anulación de la transacción por vicio resultante de error esencial de derecho.

(6) Anulación de la transacción por vicio resultante de error esencial sobre la cantidad (in cuantitate).

(7)Anulación de la transacción por vicio resultante de error en el motivo o falsa causa. 
(8)Anulación de la transacción por vicio resultante de error en la declaración, referido a la naturaleza del acto.

(9)Anulación de la transacción por vicio resultante de error en la declaración, referido al objeto principal de dicha declaración.

(10) Anulación de la transacción por vicio resultante de error en la declaración, referido a la identidad de la persona.

(11) Anulación de la transacción por vicio resultante de dolo por acción.

(12) Anulación de la transacción por vicio resultante de dolo por omisión.

(13) Anulación de la transacción por vicio resultante de dolo proveniente de un tercero.

(14) Anulación de la transacción por vicio resultante de intimidación.

(15) Anulación de la transacción por vicio resultante de violencia.

(16) Anulación de la transacción por haber sido celebrada con simulación relativa.

(17) Anulación de la transacción por mandato legal.

(18) Nulidad de la transacción por ausencia de la manifestación de voluntad del agente.

(19) Nulidad de la transacción por haberse practicado por persona absolutamente incapaz.

(20) Nulidad de la transacción por tener objeto físicamente y/o jurídicamente imposible.

(21) Nulidad de la transacción por tener objeto indeterminable.

(22) Nulidad de la transacción por tener fin ilícito.

(23) Nulidad de la transacción por adolecer de simulación absoluta.

(24) Nulidad de la transacción por no revestir la forma prescrita bajo sanción de nulidad.

(25) Nulidad de la transacción cuando la ley así lo declare.

(26) Nulidad de la transacción cuando sea contraria a las leyes que interesan al orden público o a las buenas costumbres.

(27) Rescisión del acto transaccional por existir vicio de lesión ${ }^{57}$.

57 Por nuestra parte, debemos decir que consideramos que un contrato viciado de lesión sí podría rescindirse, incluso si se tratara de una transacción, a pesar de lo dispuesto por el artículo $1455^{\circ}$, inciso 1 , del Código Civil peruano.

Pensamos que es válida la prohibición de rescindir una transacción viciada de lesión si este 
(28) Rescisión del acto transaccional por ser ajeno uno de los bienes materia de la transacción ${ }^{58}$.

(29) Rescisión del acto transaccional por ser parcialmente ajeno uno de los bienes materia de la transacción.

(30) Rescisión del acto transaccional si el mismo implica o incluye una compraventa sobre medida.

(31) Rescisión del acto transaccional por alguna otra causal prevista por el código civil o cualquier otra norma legal ${ }^{59}$.

(32) Resolución de la transacción por incumplimiento ${ }^{60}$.

(33) Resolución por excesiva onerosidad de la prestación.

(34) Resolución del acto transaccional por existir un supuesto de evicción.

(35) Resolución del acto transaccional por existir un vicio oculto.

vicio sólo estuviese configurado por el elemento objetivo de la desproporción en el valor de las prestaciones, ya que la razón de ser de la transacción no estriba en la equiparidad de las concesiones recíprocas, sino en sortear, de común acuerdo, la dificultad en que se entramparon las partes. En estos casos, permitir que se pueda interponer una acción por lesión sería entorpecer el objetivo mismo de la transacción, que es -precisamente- evitar un pleito o finalizar el ya iniciado. La agilidad y fluidez obtenida se perderían. Sería como borrar con una mano lo que se escribió con la otra. En este caso sería más útil y menos oneroso para las partes ir a juicio que transigir.

Sin embargo, ¿qué ocurre en el caso de demostrarse que una de las partes se aprovechó del estado de necesidad de la otra, forzando un acuerdo nada equitativo? ¿qué ocurre, en un caso de mala fe?

Reconocemos que sería cuestionable rescindir la transacción en lo que respecta a su carácter objetivo, pero pensamos que resultaría incuestionable manifestarnos a favor de la misma si se presentaran los elementos subjetivos a que hemos hecho referencia.

58 Si uno de los bienes materia de la transacción tuviese el carácter de ajeno, vale decir que no perteneciera a la parte que se compromete a transferir su propiedad en aras de solucionar el asunto dudoso o litigioso, dicha transacción sería rescindible por aplicación analógica de lo dispuesto por el artículo $1539^{\circ}$ del Código Civil.

59 Es evidente que resultaría factible demandar la rescisión de una transacción en caso de que esta última contenga una causal de rescisión contemplada por el Código Civil o por cualquier otra ley vigente en la República.

60 Como hemos dicho en reiteradas ocasiones, de acuerdo a lo dispuesto por el artículo $1302^{\circ}$ del Código Civil, con las concesiones recíprocas materia de la transacción también se pueden crear, regular, modificar o extinguir relaciones diversas de aquellas que han constituido objeto de controversia entre las partes. Si la transacción fuese creadora de obligaciones, las cuales fueran incumplidas por una de las partes, resultaria de aplicación lo prescrito por los artículos $1428^{\circ}$ y siguientes del Código Civil, los mismos que facultan al contratante perjudicado (en un contrato con prestaciones recíprocas) a solicitar -judicial o extrajudicialmente- la resolución de la relación contractual (con la salvedad de si se trata de una resolución judicial, caso en el cual no cabe resolver el contrato de transacción). 
(36) Resolución del acto transaccional por presentarse alguna otra causal contemplada por las partes o prevista por la ley.

\section{Diferencias y semejanzas existentes entre la transacción y otras figu- ras jurídicas.}

\section{(a) Transacción y sentencia.}

La transacción sólo tiene similitudes con la sentencia o con el laudo, cuando nos encontremos dentro de un proceso judicial o arbitral, respectivamente.

De acuerdo al ordenamiento legal peruano, dicha transacción -que pondría fin al litigio o arbitraje- debería ser aprobada por la autoridad judicial o arbitral que conoce del asunto materia de la transacción, pero no debe confundirse la transacción con la sentencia o con el laudo, por más que éstos últimos recojan completamente el sentido de dicha transacción, pues la transacción es un acto motivado por la voluntad de las partes, en tanto la sentencia o el laudo provienen de un acto de la autoridad. En los casos de transacción judicial o arbitral, la sentencia constituye el acto que sigue al acuerdo transaccional y es una mera consecuencia de este último. Con la transacción las partes obligan a la autoridad que conoce de litigio a reconocer la validez de sus pareceres y, en tal virtud, al haber llegado a un arreglo, simplemente declaran extinguido el proceso judicial o arbitral.

La sentencia que aprueba una transacción judicial o el laudo que aprueba una transacción arbitral tienen, por tanto, características meramente declarativas y no constitutivas de derechos.

(b) Transacción y juramento decisorio.

El juramento decisorio cra un medio probatorio previsto por el antiguo Código de Procedimientos Civiles de 1912, que consistía en ofrecer como prueba la "confesión" de la contraparte, pero con algunas peculiaridades. Esta era una prueba a la cual los litigantes casi nunca recurrían, pues, en la práctica, implicaba que el proceso terminara con una sentencia que recogiese íntegramente la declaración de la contraparte (la misma que, como resulta obvio, era altamente improbable 
que fuese favorable a las pretensiones de aquel que ofrecía como prueba dicho juramento decisorio).

Las diferencias entre el juramento decisorio y la transacción son ostensibles, en la medida que la transacción importa concesiones recíprocas que las partes se hacen mutuamente, en tanto que el primero implica el que una parte se someta a la decisión o parecer de la contraria en un proceso judicial. Podría decirse que en el juramento decisorio existe una voluntad de la parte que lo ofrece, destinada a aceptar lo que manifieste la parte contraria. Ello, por cierto, no implica concesiones recíprocas, sino únicamente la concesión de una parte respecto de la otra, pues quien tiene que deferir juramento decisorio podría no ceder en absoluto en su posición original, y de esta forma la sentencia judicial a través de la cual concluya el proceso tendría que recoger en su integridad los argumentos sostenidos en todo tiempo por una de las partes.

Por último, el juramento decisorio sólo puede tener lugar dentro de un proceso judicial, en tanto que la transacción puede ser judicial o extrajudicial.

\section{(c) Transacción y compromiso arbitral.}

En el "compromiso", por más que intervienen todas las voluntades en juego, no se pone fin a la controversia, y solamente se designan jueces privados, en sustitución de la vía jurisdiccional.

Podemos decir que la transacción difiere sustancialmente del compromiso arbitral, ya que cuando las partes celebran una transacción tienen plena conciencia de cuáles son los derechos que cede cada una de ellas en favor de la otra. En cambio, cuando ambas partes someten al arbitraje un asunto de carácter dudoso, con la finalidad de que un tribunal arbitral solucione dicha controversia, no conocen por anticipado cuál será la decisión (laudo) que expida ese tribunal arbitral.

Sin embargo, la transacción y el compromiso arbitral tienen similitud en un aspecto: el referido a que si existe un asunto controversial entre dos partes y ambas acuerdan someter su decisión a un laudo expedido por un tribunal arbitral, con ello están, en cierto modo, efectuándose concesiones de carácter recíproco, pues están acordando que aceptarán lo que dicho tribunal arbitral resuelva sobre la controversia existente. 


\section{(d) Transacción y confirmación.}

La transacción no es ni una confirmación ${ }^{61}$ ni una ratificación (que es un negocio unilateral, sin concesiones recíprocas ni concurso de ambas voluntades).

Son marcadas las diferencias entre la transacción y la confirmación, según se desprende de los arrículos $230^{\circ}, 231^{\circ}$ y $232^{\circ}$ del Código Civil. Por lo demás, el ámbito de la confirmación no sólo estaría restringido a los actos jurídicos anulables, sino también a los contratos que se ven afectados por un vicio de rescisión (ello, pues al no existir precepto alguno que prohíba confirmar un acto rescindible, se entiende que tal confirmación resulta jurídicamente aceptable).

\section{(e) Transacción y renuncia.}

Una serie de categorías, vistas en forma aislada, como la renuncia, el desistimiento y el reconocimiento, dependen de una sola parte interesada, faltando uno de los rasgos esenciales de la transacción, a saber, la bilateralidad en las concesiones.

No obstante, la renuncia reviste cierta similitud con la transacción, en la medida que a través de la transacción, en las denominadas concesiones recíprocas que se efectúan las partes, existe una renuncia de cada una de ellas a sus pretensiones de origen, en tanto aceptan la posibilidad de llegar a un acuerdo en el que existe una cesión a favor de su contraparte. Puede decirse, sin error, que no hay transacción sin renuncia; pero igualmente debe precisarse que para que exista transac-

61 La confirmación es una figura relativa a los actos jurídicos, la misma que se encuentra regulada en el Título X del Libro de Acro Jurídico del Código Civil peruano, artículos $230^{\circ}$, $231^{\circ}$ y $232^{\circ}$ :

Artículo $230^{\circ}$.- "Salvo el derecho de tercero, el acto anulable puede ser confirmado por la parte a quien corresponda la acción de anulación, mediante instrumento que contenga la mención del acto que se quiere confirmar, la causal de anulabilidad y la manifestación expresa de confirmarlo."

Artículo $231^{\circ}$.- "El acto queda también confirmado si la parte a quien correspondía la acción de anulación, conociendo la causal, lo hubiese ejecutado en forma total o parcial, o si existen hechos que inequivocamente pongan de manifiesto la intención de renunciar a la acción de anulabilidad."

Artículo 232\%.- "La forma del instrumento de confirmación debe tener iguales solemnidades a las establecidas para la validez del acto que se confirma." 
ción, dicha renuncia debe tener carácter bilateral. Si la renuncia a los derechos fuese unilateral, no estaríamos en presencia de una transacción, sino de una condonación total o parcial, dependiendo de cuál sea su magnitud.

(f) Transacción y donación.

La transacción no es susceptible de ser confundida con la donación, debido a que en ésta una de las partes actúa con un espíritu de liberalidad (animus donandi), en tanto que en la transacción este elemento no existe, pues ambas partes actúan en función de su propio interés.

Si bien puede ser calificada como un contrato, la transacción es también un medio extintivo de obligaciones, característica con base en la cual ha recibido tratamiento legislativo en el Código de 1984. La donación, en cambio, es un contrato típico, en el que una parte (donante) se obliga a transferir la propiedad de un bien, de manera gratuita, a otra parte (donatario). Es en virtud de estas consideraciones que a pesar de que algunos autores consideren necesario hacer un deslinde entre ambas figuras, estimamos que las diferencias son tan claras y ostensibles que tan sólo justifican un escueto comentario.

(g) Transacción y condonación.

La condonación es el perdón de una deuda acordado entre acreedor y deudor. No interesa si para llegar a dicha condonación nos encontramos en presencia de una deuda de carácter dudoso. Lo que interesa es que el acreedor convenga con el deudor en que no se cobrará la misma ni total ni parcialmente, lo que equivale a decir que deciden extinguirla sin que se haya ejecutado. En otras palabras, la condonación implica solamente la renuncia o concesión de los derechos de una de las partes hacia la otra, en tanto que la transacción implica una renuncia recíproca o concesiones recíprocas.

(h) Transacción y mutuo disenso.

La transacción es un medio no sólo extintivo de obligaciones, pues también puede ser modificatorio, regulatorio o creador de las mismas, e incluso cumplir varias de estas funciones a la vez. Por su parte, el mutuo disenso sólo cumple una función extintiva. 
En segundo término, la transacción sólo es aplicable al Derecho Patrimonial (argumento del artículo $1305^{\circ}$ del Código Civil), en tanto que el mutuo disenso también tiene relevancia dentro del Derecho de Familia, tal como se puede apreciar en el caso de la separación y ulterior divorcio por causal de mutuo disenso (ahora llamada separación convencional).

Luego, la transacción debe versar sobre un asunto de carácter dudoso o litigioso; en cambio, el mutuo disenso no tiene por qué presentarse ante un asunto de esta naturaleza, ya que puede no haber duda alguna respecto de la materia acerca de la cual las partes celebran dicho mutuo disenso, en la medida que el mismo podría originarse, incluso, por la voluntad arbitraria de ambos contratantes.

Finalmente, la transacción puede resolver un asunto dudoso o litigioso nacido de fuente extracontractual o ajeno al convenio de aquellos que han celebrado un acto jurídico (como es el caso, por ejemplo, de la transacción celebrada sobre responsabilidad extracontractual); en cambio, el mutuo disenso sólo recae sobre actos jurídicos (ya sea de naturaleza patrimonial o extrapatrimonial) que las partes hayan celebrado anteriormente.

Necesidad de que la transacción contenga renuncia expresa de cualquier acción futura.

El artículo $1303^{\circ}$ del Código Civil exige la formalidad de esta renuncia en el acuerdo transaccional. El sentido del precepto resulta evidente, tomando como punto de partida la finalidad de la transacción, su razón de ser. Esta es, como sabemos, no reabrir el asunto que dejó de ser controvertido, dudoso o litigioso. Terminar el pleito judicial en curso o evitar iniciar uno. La eficiencia y practicidad, que constituyen las ventajas de la transacción, giran alrededor de esta economía en términos de tiempo, recursos e incertidumbre. Estos beneficios se tornarían estériles si la transacción no tuviera la calidad de definitiva, es decir, si pudiera iniciarse, reiniciarse o proseguir un proceso judicial sobre el mismo tema al cual las propias partes encontraron solución y convinieron en ella.

Puesto que los efectos de no revisar dicho acto se deducen de la naturaleza misma de la transacción, siendo ésta irrevisable, no se reque- 
riría, en estricto, efectuar la precisión que este artículo efectúa de modo imperativo. En cualquier caso, habiéndose señalado en la norma que define a la transacción su valor de cosa juzgada, resulta incuestionable que las partes ya no podrán promover acción alguna sobre el asunto transigido.

Nos parece que el requisito que el legislador ha establecido de consignar en la transacción la renuncia de las partes a cualquier acción que tenga la una contra la otra sobre el objeto de dicha transacción, es más de carácter recordatorio para las partes respecto del punto final que están poniendo a la discusión, que un verdadero imperativo legal.

Por ello, ante la posible interrogante respecto a lo que podría ocurrir si al celebrarse una transacción las partes no expresaran por escrito dicha renuncia, consideramos que tal omisión no acarrearía necesariamente la nulidad o ineficacia del acuerdo transaccional, por más que la norma sea de carácter imperativo (emplea el término "debe"). La renuncia constituye, a nuestro entender, un agregado menos necesario para el Derecho, que útil para las partes contratantes, en el sentido de solo recordarles que la transacción celebrada no podría impugnarse en el futuro (esto en términos psicológicos, ya que tales seguridades de todas formas existen, puesto que la renuncia está implícita en la transacción misma). Parece conveniente, sin embargo, no omitir tales expresiones en una transacción, porque un juez rigorista podría fulminarla de nulidad.

\section{Forma de la transacción.}

La transacción es un contrato formal, ya que la ley le impone una forma, bajo sanción de nulidad (ad solemnitatem). Es requisito indispensable para su formación o celebración el que se celebre por escrito, en el caso de la transacción extrajudicial o por petición al juez (evidentemente también por escrito) en el caso de la transacción judicial. Esto no obsta, naturalmente, para que existiendo juicio las partes puedan transigir por convenio privado y cualquiera de ellas presentar un ejemplar del mismo en el litigio, con lo que concluiría el proceso.

Es claro que habiendo considerado la existencia previa de un contrato o relación jurídica obligacional, además de un conflicto respecto de algún punto interno de ésta, sumado a los actos de disposición que 
implican las concesiones recíprocas y al carácter de cosa juzgada de la transacción, el legislador de 1984 llegó a la conclusión de que era indispensable otorgar seguridad jurídica plena a las partes exigiendo una formalidad ad solemnitatem. Esto se da tanto en la transacción judicial, como en la extrajudicial ${ }^{62}$.

Esto quiere decir que en el caso de la transacción la forma es constitutiva del acuerdo; sin la forma no existe la transacción. Es de gran importancia que dichas concesiones mutuas consten por escrito, a fin de que ambas partes tengan a su alcance un medio accesible para probar la existencia de un acuerdo en tal sentido, el mismo que es irrevisable en el Poder Judicial.

\section{Derechos sobre los que se puede transigir.}

El artículo $1305^{\circ}$ del Código Civil peruano de 1984 prescribe que únicamente los derechos patrimoniales pueden ser objeto de transacción. El sentido de esta disposición es claro: los derechos extrapatrimoniales, esto es los derechos inherentes a la persona, no son susceptibles de renuncia por las partes. En este punto la doctrina no tiene resquicios de discrepancia, admitiendo como materia de transacción a todos los derechos dudosos o litigiosos que siendo de interés privado y estando en el comercio sean susceptibles de disposición y renuncia por los particulares.

Sabemos que los derechos extrapatrimoniales no pueden formar parte de los contratos, encontrándose fuera del comercio de los hombres, por lo que se infiere claramente que no pueden ser objeto de transacción. Y ello porque la transacción, siendo un medio para extinguir obligaciones, es básicamente un mecanismo contractual.

62 El Código Procesal Civil de 1993 exige expresamente el documento escrito con firmas legalizadas ante el Secretario Judicial:

Artículo $335^{\circ}$.- "La transacción judicial debe ser realizada únicamente por las partes o quienes en su nombre tengan facultad expresa para hacerlo. Se presenta por escrito, precisando su contenido y legalizando sus firmas ante el Secretario respectivo. Si habiendo proceso abierto las partes transigen fuera de éste, presentarán el documento que contiene la transacción legalizando sus firmas ante el Secretario respectivo en el escrito en que la acompañan, requisito que no será necesario cuando la transacción conste en escritura pública o documento con firma legalizada." 
Los derechos extrapatrimoniales son irrenunciables, por lo que no son objeto de transacción. Por ejemplo, todo lo concerniente a la persona humana (como el derecho a la vida, a la salud, al trabajo, a la personalidad, a la capacidad, a la nacionalidad o al estado civil), a la organización de la familia, a la filiación, a las obligaciones o deberes y a los derechos o facultades que la ley confiere a los padres, tutores, curadores o a los cónyuges, comprometen al orden público. Son deberes y derechos intransferibles y, por ende, intransigibles.

$\mathrm{Al}$ interior del ámbito de los contratos, como se conoce, las personas pueden obligarse de las más variadas formas, sin poder, claro está, asumir obligaciones respecto de bienes y derechos que se encuentran fuera del comercio de los hombres. Por ello es que los contratos y, por ende, la transacción, no pueden versar sobre esta clase de bienes.

De lo expresado podría inferirse que la norma bajo comentario resulta inútil, ya que la prohibición de transigir respecto de derechos extrapatrimoniales es obvia. Pero, hasta cierto punto, al Derecho le interesa sacrificar tecnicismos en aras de proveer de claridad a temas claves (de alguna manera esta norma nos recuerda la reiterada restricción contractual en el sentido que los contratos sólo surten efecto entre quienes los celebran, no pudiendo causar perjuicio a terceros).

Es evidente que no pueden ser materia de transacción los derechos de los padres sobre los hijos, el estado de las personas, etc., pues en estos casos, aparte del interés privado que está en juego, también se encuentra el interés público, ya que se trata de instituciones de interés colectivo. En efecto, las personas no pueden renunciar a una situación que les corresponde por derecho de manera irrevocable, pues todos y cada uno de nosotros tenemos una filiación, un estado civil, etc., de carácter irrenunciable, por lo que cualquier transacción relativa a esos puntos sería absolutamente nula. Y ciertamente se considera dentro de los derechos patrimoniales a aquellos de carácter absolutamente pecuniario que se encuentran en relación con estos derechos personales o de estado. Estos últimos no podrán disponerse, pero los primeros sí. De esa forma, una persona no puede transferir (por tanto transigir) sus derechos de autor o de carácter intelectual sobre una creación artística o un invento científico, pero sí puede transferir las regalías o los derechos de carácter pecuniario derivados de éstos. 


\section{La transacción sobre un proceso judicial ya concluido.}

Hemos visto que hay derechos que siendo patrimoniales (como en el caso de los alimentos), no son susceptibles de transacción. También es inválida la transacción respecto de bienes y derechos patrimoniales en caso de ignorancia respecto de tales bienes o derechos. Este sería el caso de quien realiza una concesión respecto de un derecho que ignoraba haber adquirido por sentencia. Si, por ejemplo, dos personas se encuentran disputando judicialmente la propiedad de un inmueble, y el juez dicta sentencia en favor de una de ellas, y ésta, sin saber que el fallo ha sido emitido, renuncia a favor de la otra parte (que ha sido vencida en el juicio), dicha transacción sería indudablemente nula en todos los $\operatorname{casos}^{63}$, salvo que dicha sentencia no constituyera última instancia, y pudiese ser revisada en apelación. De ser éste el caso, la doctrina se inclina a otorgarle plena validez a la transacción.

\section{Transacción sobre responsabilidad civil proveniente de delito.}

Sabemos que no se puede transigir sobre derechos que se hallen fuera del comercio de los hombres, encontrándose dentro de este rubro las acciones penales, por interesar al orden público y escapar al ámbito de los particulares ${ }^{64}$. Sin embargo, caso distinto es la responsabilidad civil

63 Hay dos posibilidades: una, que ambas partes ignoraban la sentencia antes de la transacción, en cuyo caso al transigir se encontraban en el estado de duda o incertidumbre que los motivó a celebrar la transacción. La otra posibilidad es que la parte perdedora del juicio hubiese conocido la sentencia, por lo que habría actuado de mala fe, lo cual -todavía con mayor razón- da peso al fundamento que anula la transacción. No consideramos la posibilidad de que el ganador del juicio hubiese conocido su resultado antes de transigir, por resultar esto un absurdo.

64 Si bien los delitos y las faltas interesan -y en ocasiones vivamente- a las partes comprometidas en dichos actos (en los que hayan podido intervenir como sujetos activos o pasivos), la reparación civil es la parte privada de esta relación. El campo penal es materia de Derecho Público, puesto que interesa a toda la sociedad, representada y tutelada por el Estado, el mismo que se encarga de castigar al sujeto que agrede la seguridad de la sociedad con su conducta. Es el Estado, mediante el Derecho Penal, quien protege a los ciudadanos recluyendo al criminal. Es el Estado el encargado de readaptar al delincuente para que pueda insertarse de manera productiva (o al menos inofensiva) en la sociedad. Al respecto, y como anotación al margen, cabe señalar que el análisis económico del Derecho considera que las penas son muy importantes, ya que mediante éstas el potencial infractor puede ser desmorivado a cometer el 
que proviene del delito, ya que trata de intereses puramente económicos, es decir, susceptibles de disposición y, por tanto, transigibles.

En la mayoría de delitos, ocurrirá que de ellos se derive cierta responsabilidad civil, ya sea titular de ésta el Estado o algún particular. El Código Civil peruano señala claramente que sobre esta materia sí cabe transigir. El Estado no considera de interés público la responsabilidad civil derivada de actos delictuales. En este aspecto los particulares tienen la más amplia libertad para concertar una transacción.

Este tema es regulado en forma muy similar por los códigos civiles uruguayo, ecuatoriano, venezolano, chileno, boliviano, guatemalteco, español, brasileño y argentino.

En base a lo señalado, podemos resumir que las sanciones penales reconocen un fundamento supraindividual (lo que puede denominarse el "bien común"), mientras que las sanciones civiles pertenecen, como principio, a la órbita de la autonomía de la voluntad.

Ahora bien, hay categorías de delitos sobre los cuales es difícil determinar si su esfera pertenece íntegramente al Derecho público, como el caso de aquellos cuya sanción se persigue por vía privada, por acción del propio ofendido. Estos delitos de acusación meramente privada son, por ejemplo, la injuria, la difamación, la calumnia, la competencia desleal, la violación de secretos y ciertos delitos contra la moral. En estos casos se vuelven algo difusas las razones por las cuales no se puede transigir en lo referente a la acción penal (la que es en principio pública, pero aquí, más bien, resulta siendo privada), ya que su persecución solo incumbe a la persona damnificada. En estos casos nada obsta para que el perjudicado, que tiene la potestad de renunciar a su acción, pueda transigir respecto a ella (quien puede lo más, puede lo menos).

Resulta evidente que si cabe transigir acerca de la responsabilidad civil proveniente de delito o falta, con mayor razón será posible transigir sobre la responsabilidad civil proveniente de cualquier ilícito civil que no llegue a revestir tal carácter en el ámbito del Derecho penal.

delito, pues al realizar su análisis costo-beneficio puede llegar a la conclusión de que es mejor abstenerse de delinquir. De ahí la relevancia de establecer penas adecuadas e inteligentes. Por ejemplo, si se aplicase la pena de muerte para un violador (tema que se estuvo debatiendo hace poco en el Congreso de la República), para el análisis económico ello no sería eficiente, ya que el violador se sentiría motivado para asesinar a su víctima, a fin de reducir el riesgo de ser delatado por ella, que en buena cuenta usualmente constituye el único testigo. 


\section{Transacción efectuada por representantes legales de ausentes o in- capaces.}

El artículo $1307^{\circ}$ del Código Civil peruano tiene como finalidad regular la transacción celebrada por los representantes de ausentes e incapaces, siendo un caso bastante especial, ya que éstos requieren la máxima protección por parte del ordenamiento jurídico, particularmente si se trata de realizar concesiones recíprocas, que no son otra cosa que disposiciones de bienes y derechos.

Entonces, puesto que la transacción supone dichas concesiones, las mismas que pueden consistir en verdaderas renuncias o disminución de derechos, resulta indispensable cautelar el interés de los ausentes e incapaces, mediante la exigencia imperativa a sus representantes legales de obtener la aprobación del juez, quien por su parte debe oir previamente al Ministerio Público y al consejo de familia (si lo hubiere).

Siendo ésta la regla general para el caso de todos los incapaces y ausentes, es menester armonizarla con los preceptos específicos que contempla el Código Civil respecto a cada uno de ellos.

Así, en el caso de los ausentes ${ }^{65}$, son aplicables los artículos $52^{\circ}$ y $56^{\circ}$ del Código Civil, que establecen que quienes hubiesen obtenido la posesión temporal de los bienes de los ausentes no pueden gravarlos ni menos aún enajenarlos, salvo casos de necesidad, en la medida de lo indispensable y previa autorización judicial.

En cuanto a los incapaces, se entiende que dentro del término "incapaces" el artículo $1307^{\circ}$ comprende tanto a los incapaces absolutos como a los relativos, ya que ambos no cuentan con capacidad de ejercicio plena; y ambos, por disposiciones del propio Código, deben contar con representantes.

La norma general sobre representantes legales prescribe que requieren autorización expresa para disponer de los bienes del representado o gravarlos; celebrar transacciones; celebrar compromiso arbitral; y celebrar los demás actos para los que la ley o el acto jurídico exigen autorización especial (artículo 167 del Código Civil).

65 Como sabemos, ausentes son los desaparecidos de quienes no se haya tenido noticia en dos o más años, y que el juez, a pedido de quien tenga legítimo interés, los hava declarado en tal condición (situación jurídica de ausencia). 
En el caso de menores sujetos a patria potestad, para transigir se exige a los padres obtener autorización judicial (inciso 3 del artículo $448^{\circ}$ del Código Civil). En concordancia con el artículo $447^{\circ}$, los padres no tienen la facultad de enajenar ni gravar los bienes de los hijos, ni contraer en nombre de ellos obligaciones que excedan los límires de la administración, salvo por causas justificadas de necesidad o utilidad y previa autorización judicial. Entonces el juez deberá verificar y evaluar la existencia de necesidad o utilidad.

Para los menores sujetos a tutela, el artículo $532^{\circ}$, inciso 1 , del Código Civil establece que los tutores no podrán obtener la aprobación judicial, si no se da audiencia previa del consejo de familia, en resguardo de los intereses del menor.

\section{La transacción celebrada a través de apoderado.}

Sabemos que para transigir se requiere capacidad de disponer, habida cuenta de que quien transige renuncia a derechos, enajena o pierde bienes que se encontraban en su patrimonio. La transacción es, pues, un acto de disposición.

Es claro, entonces, que cuando se habla de transacción por medio de apoderado, éste requiere contar con poder especial, porque el mandato general sólo comprende los actos de administración ordinaria, que son aquellos para los que ha sido conferido, además de los que sean necesarios para su cumplimiento (artículo $1792^{\circ}$ del Código Civil). El mandato para asuntos específicos como transacciones, o cualquier acto que implique disposición de bienes o derechos, necesita poder especial. $\mathrm{Al}$ respecto, el artículo $156^{\circ}$ del Código Civil establece que para disponer de la propiedad de los bienes del representado o gravarlos, se requiere que el encargo conste en forma indubitable y por escritura pública, bajo sanción de nulidad. Se trata de una formalidad ad solemnitatem, considerando lo severas que son sus consecuencias.

\section{Transacción sobre nulidad o anulabilidad de la obligación. Efectos.}

Resulta necesario distinguir la nulidad de la anulabilidad en las transacciones. La nulidad tiene lugar de pleno derecho, independientemente 
de la voluntad de las partes. En caso de anulabilidad, la nulidad existe potencialmente (el acto tiene una "validez actual", pero una "invalidez pendiente"); sólo se requiere que el magistrado la compruebe y la declare (artículo 2220: "El acto jurídico anulable es nulo desde su celebración, por efecto de la sentencia que lo declare. Esta nulidad se pronunciará a petición de parte y no puede ser alegada por otras personas que aquellas en cuyo beneficio la establece la ley.").

Una vez pronunciada la sentencia que declara la nulidad, ya no es posible transigir, porque la transacción se refiere a la acción que pueden intentar las partes respecto de una obligación o un asunto que existe, y la nulidad lo ha eliminado: ya no existe. No se puede transigir sobre lo que ya no existe. Por ello la transacción también es nula. Entonces están excluidas de la transacción las obligaciones que adolezcan de nulidad absoluta y las obligaciones anulables que han sido judicialmente declaradas nulas.

La primera parte del artículo $1308^{\circ}$ del Código Civil peruano de 1984 resulta, pues, una norma que fluye de la lógica jurídica. En realidad, sin ella también podríamos llegar a similar conclusión que la planteada en su texto. Y es natural, por la sencilla razón de que nada cabe hacer en nuestro Derecho, para que algo nulo deje de serlo. Un acto nulo tiene esta calidad y la tendrá siempre. No cabe convalidarlo porque no existe (independientemente de la distinción teórica entre inexistencia y nulidad, ajena a nuestro Derecho positivo). Y de admitirse principio contrario al establecido en la norma bajo comentario, se estaría dejando abierta una vía para que lo nulo, bajo la forma de una transacción posterior, pudiese llegar a tener algún valor para el Derecho y, por tanto, surtir efectos, solución que, además de absurda, sería muy peligrosa.

Ahora bien, cabría formularse las siguientes interrogantes: ¿qué ocurre con los actos nulos (que aun no han sido declarados tales) cuando ha vencido el plazo prescriptorio para la acción de nulidad? ¿Dejan de ser nulos? Nuestro Código Civil vigente, en su artículo 2001º, inciso 1 , establece un plazo prescriptorio específico para la acción de nulidad, fijándolo en diez años (el mismo plazo prescriptorio que para la acción personal). Por tanto, hay un límite a la perpetuidad de la nulidad absoluta, pero debido a su gravedad se ha establecido un plazo de prescripción muy amplio. 
Al respecto, Fernando Vidal Ramírez ${ }^{66}$ recuerda que no siempre se ha reconocido la aptitud de la prescripción en relación al acto nulo, y esto en razón de la máxima quod initio vitiotum est non potest tractu temporis convelecere (lo que es inicialmente vicioso no puede convalecer por el transcurso del tiempo). En virtud de esta máxima, a lo largo de varias centurias se ha sostenido la perpetuidad de la nulidad y, con ella, la imprescriptibilidad de la acción.

"Fue el Código de Napoleón el que puso un límite a la perpetuidad de la nulidad absoluta tornando prescriptible la acción al disponer, su artículo $2262^{\circ}$, que todas las acciones que no tuvieran otro plazo fijado debían prescribir a los 30 años. Nuestro Código de 1852 , si bien estableció en su artículo $2300^{\circ}$ con la terminología que utilizaba, que la acción para rescindir los contratos declarados nulos por la ley durante dos años contados desde la fecha del acto, la excepción para librarse de su cumplimiento era perpetua, lo que llevó a los codificadores de 1936 a establecer un plazo prescriptorio.

El Código de 1936 , en su artículo $1169^{\circ}$, dispuso la prescriptibilidad de la acción de nulidad en el plazo de 30 años, fijando el Artículo $1170^{\circ} \mathrm{el} \mathrm{mismo}$ plazo prescriptorio para deducir la excepción, rompiendo este último la perpetuidad de la excepción. (...)

Estos antecedentes explican que el inciso 1 del artículo $2001^{\circ}$ del Código vigente haga referencia específica a la acción de nulidad, aunque le fije el mismo plazo prescriptorio que fija para la acción personal en general." ${ }^{6}$.

No olvidemos que la transacción se celebra necesariamente (cuando tiene como base actos y no hechos jurídicos -caso de la responsabilidad extrancontractual-) a partir de actos jurídicos previos que hayan dado origen a las obligaciones o materias ahora controversiales. En tal sentido, apoyará todos sus fundamentos en estos actos primigenios. Y por lo tanto, su eficacia o posibilidad de eficacia estará en relación directa con la de dicho acto. Así, los vicios que afecten al primer acto, afecta-

66 Fernando Vidal Ramírez. Prescripción Extintiva y Caducidad. Gaceta Jurídica Editores, Lima, 1996, p. 140.

67 Ibid., pp. 140 y 141 . 
rán también al segundo. Aquí tenemos dos actos que si bien parecen independientes uno del otro, no lo son en realidad. De allí que si el acto primitivo fuese nulo, la transacción que versa sobre el mismo también lo sería, siendo irrelevante el hecho de que las partes hubiesen conocido acerca de esta nulidad.

Distinto es el caso en que el acto primigenio no fuese nulo sino anulable. En este supuesto, el código brinda una solución distinta: si las partes conocían de la anulabilidad del acto, y a sabiendas celebran una transacción sobre el mismo, dicha transacción sí revestirá validez, debido a que la ley supone que a través de la realización de este segundo acto se está produciendo una confirmación tácita del primero. Decimos confirmación tácita, ya que en virtud del artículo $231^{\circ}$ del propio código se establece que el acto queda confirmado si la parte a quien correspondía la acción de anulación, conociendo la causal, lo hubiese ejecutado en forma total o parcial, o si existen hechos que inequívocamente pongan de manifiesto la intención de renunciar a la acción de anulabilidad; y, sin lugar a dudas, celebrar una transacción, sabiendo que el acto originario era anulable, configuraría un supuesto de confirmación del acto jurídico.

Así, la transacción celebrada en estas circunstancias, tendría un doble efecto: por una parte, confirmaría un acto jurídico, y por otra, constituiría una transacción propiamente dicha, que ponga solución a controversias suscitadas o derivadas del acto originario.

La solución otorgada por el Código Civil a los supuestos de transacciones que versen sobre actos nulos o anulables es distinta, en razón de que mientras el acto nulo es un acto sin vida, con invalidez total y perpetua (con la salvedad de la prescripción de la acción de nulidad), el acto anulable, como hemos manifestado, es un acto de invalidez actual, pero de una invalidez pendiente, latente, como "en suspenso", la misma que podrá o no tener lugar, dependiendo de si la parte que tiene derecho a ejercitar acción al respecto decide anularlo a través de la vía judicial, o si lo confirma posteriormente.

Supuesto en el cual la cuestión sobre la que se transige sea precisamente la nulidad o anulabilidad del acto.

No debemos confundir la transacción celebrada sobre actos nulos o 
anulables con la transacción sobre la nulidad o anulabilidad de dichos actos.

En efecto, el artículo $1309^{\circ 68}$ trata de los supuestos en que la materia central de la transacción sea zanjar las diferencias existentes entre las partes sobre si el acto originario era nulo, o sobre si el acto originario era anulable. De no adoptarse este criterio, sería imposible transigir respecto a actos jurídicos cuya nulidad o validez se discuta.

Creemos que se podría esbozar una interpretación en el sentido de que en el caso de los actos nulos de pleno derecho, la transacción sobre dicha nulidad no sería válida, a pesar de lo expresado por nuestra norma positiva. La nulidad absoluta quiere decir que el acto jamás se celebró, por lo que no cabría transigir sobre algo que no existe. En cualquier caso, las partes podrían intentar celebrar otro acto nuevo que no adolezca de nulidad.

Para entender mejor este criterio, recordemos los supuestos de nulidad absoluta: cuando falta la manifestación de voluntad del agente (en cuyo caso jamás hubo acto jurídico y lo que se llamaría "transacción" vendría a ser en realidad el primer acto jurídico y no el segundo); cuando se haya practicado por persona absolutamente incapaz (excepto en el caso de los incapaces no privados de discernimiento que celebren contratos relacionados con las necesidades ordinarias de su vida diaria); cuando su objeto sea física o jurídicamente imposible o indeterminable; cuando su fin sea ilícito (¿cómo podría transigirse respecto de la nulidad de este acto?); cuando adolezca de simulación absoluta (¿se puede hablar de convalidar este acto?); cuando no revista la forma prescrita bajo sanción de nulidad (de este modo se esquivarían las formalidades constitutivas o ad solemnitatem, perdiendo éstas su sentido); cuando la ley lo declara nulo (¿se podría acaso ir contra la ley por convenio privado entre particulares?); y cuando el acto jurídico sea contrario a las leyes que interesan al orden público o a las buenas costumbres (transigir sobre la nulidad de este tipo de acto sería atentatorio contra el sistema mismo).

Sin embargo, nosotros nos adherimos al contenido del precepto legal, no entendiéndolo como una vía lo suficientemente amplia como para salvar nulidades evidentes, ni menos aun aquellas de orden público.

68 Artículo $1309^{\circ}$.- "Si la cuestión dudosa o litigiosa versara sobre la nulidad o anulabilidad de la obligación, y las partes así lo manifestaran expresamente, la transacción será válida." 
Creemos que existen numerosos casos en los cuales de manera legítima, vale decir, en puro Derecho, las partes pueden tener ante sí un problema derivado de la duda razonable que pudiese generar, por ejemplo, una discusión sobre si la formalidad establecida por ley para celebrar el acto que han pactado, era ad solemnitatem o ad probationem (ello, por no ser claro el texto legal). En un caso como éste, discutible en el plano jurídico, no vemos por qué razón las partes no pudiesen solucionar sus diferencias recurriendo a una transacción, la misma que podría estar referida a llegar a un acuerdo interpretativo sobre su nulidad o validez o, asumiendo la nulidad, tal acuerdo sea resultado de la creación de alguna o algunas obligaciones que pudieran no tener relación con el acto preexistente que fue materia discutible.

Además, a través de esta vía se deja abierta la posibilidad de que las partes pongan término a asuntos conflictivos de manera eficiente y rápida, sin necesidad de recurrir a los tribunales de justicia o, de ser el caso, esperar que éstos zanjen la cuestión. Es evidente, por otra parte, que al tratarse de un punto tan controvertido, la sentencia judicial podría resolver en un sentido u otro (por considerar la validez o la nulidad del acto), situación que sería reemplazada por el actuar de las propias partes, quienes (recurriendo a la vieja frase relativa a la transacción) se estarían dictando su propia sentencia.

Creemos, por último, que la transacción sería indiscutiblemente válida cuando hubiese versado sobre la anulabilidad del acto o título, tema sobre el que resulta innecesario cualquier comentario adicional.

\section{Indivisibilidad de la transacción. Efectos.}

Constituye regla general en el Derecho Peruano, respecto al tema de la divisibilidad o indivisibilidad de las nulidades en un acto jurídico, lo prescrito por el artículo $224^{\circ}$ del Código Civil ${ }^{69}$.

69 Artículo $224^{\circ}$.- "La nulidad de una o más de las disposiciones de un acto jurídico no perjudica a las otras, siempre que sean separables.

La nulidad de disposiciones singulares no importa la nulidad del acto cuando éstas sean sustituidas por normas imperativas.

La nulidad de la obligación principal conlleva la de las obligaciones accesorias, pero la nulidad de éstas no origina la de la obligación principal." 
Este precepto está enmarcado dentro del espíritu general del Código Civil de 1984, en el sentido de optar, en esa hipótesis, por la conservación de los actos jurídicos o contratos celebrados, en lugar de sancionarlos con nulidad o pérdida de eficacia ${ }^{70}$.

El artículo $1310^{\circ}$ del Código Civil peruano, relativo a la transacción, constituye la excepción a la regla del artículo $224^{0^{71}}$. Y hay motivos para ello. La transacción es un acto que tiene por objeto poner fin a un asunto controversial. Por eso, justamente, la transacción debe ser un acto que revista todas las seguridades de que en el futuro no se suscitarán problemas por el propio acto o por el acto originario.

Estima Rezzónico ${ }^{72}$ que la transacción es un acto indivisible (aunque Colmo y Lafaille observan que este carácter no es privativo o específico de la transacción, ya que cualquier contrato y convención se halla en igual caso), pues el artículo $834^{\circ}$ del Código Civil argentino dispone: "Las diferentes cláusulas de una transacción son indivisibles, y cualquiera de ellas que fuese nula, o que se anulase, deja sin efecto todo el acto de la transacción".

Para Rezzónico esto se deriva de que en la transacción el sacrificio o la concesión hecha por una de las partes representa como el precio o la condición del sacrificio de la otra.

En opinión nuestra, y salvo pacto en contrario -fruto, en este caso, de la autonomía de la voluntad-, resulta imprescindible que la transacción revista validez total. La transacción es un acto en el cual las partes

70 Sin embargo, el criterio adoptado por el Código Civil peruano no es compartido por todo el Derecho de nuestra tradición jurídica. Así, puede apreciarse el parecer de Héctor Lafaille (Curso de Obligaciones, Tipografía A.G. Rezzónico, Yapeyú 52, Buenos Aires, 1926, p. 353.), quien manifiesta respecto al tema en el Derecho Argentino, lo siguiente:

"La indivisibilidad de la transacción no constituye un carácter específico de la misma: ella es propia de todos los actos jurídicos. El principio de que no se puede dividir un acto jurídico eliminando de él determinadas cláusulas y dejando subsistentes otras, se aplica con toda amplitud, porque constituyen manifestaciones de voluntad sobre una serie de puntos determinados, y aquéllas quedarían mutiladas si se admitiera la anulación de algunas de esas cláusulas y la subsistencia de las otras; el consentimiento se ha prestado en atención a todas.

El principio de la indivisibilidad, de rigor en todos los actos jurídicos, parece más estricto, si cabe, en aquellos que son extintivos o creadores de derechos."

71 Artículo $1310^{\circ}$.- "La transacción es indivisible y si alguna de sus estipulaciones fuese nula o se anulase, queda sin efecto, salvo pacto en contrario.

En tal caso, se restablecen las garantías otorgadas por las partes pero no las prestadas por terceros."

72 Luis María Rezzónico. Op. cit., Volumen II, pp. 1027-1028. 
se hacen concesiones recíprocas. Por ello, de aceptarse el principio general del artículo $224^{\circ}$ del Código Civil, podría presentarse la situación de que una cláusula resulte nula o se anulase, y que justamente a través de esa cláusula una de las partes hiciera concesiones a la otra. Si se aceptara la validez del resto del acto, no estaríamos resolviendo un problema, sino creando otro, ya que de la transacción no se deduciría la terminación de una controversia, sino la continuación de la misma o la perpetuación de una situación injusta, bajo el manto del valor de "cosa juzgada". Como ello resultaría perjudicial para una de las partes, o incluso para ambas, la ley prefiere optar por la solución contemplada por el artículo $1310^{\circ}$, primer párrafo, del Código Civil, que establece la denominada indivisibilidad de la transacción.

\section{Carácter relativo del precepto.}

Sin embargo, según lo dicho anteriormente, por tratarse de un asunto de interés privado y no de orden público, la ley admite pacto en contrario. Este pacto puede ser previsto en el mismo acto de la transacción, o posteriormente.

Sobre este punto, Raymundo M. Salvat ${ }^{73}$ se pregunta si el principio de la indivisibilidad de las transacciones es de carácter absoluto o admite, por el contrario, algunas limitaciones. En su opinión, estando fundado este principio en una presunción de voluntad de las partes, la transacción debe considerarse divisible, $\mathrm{y}$, por consiguiente, admitirse la validez parcial de ella.

A decir de Cazeaux y Trigo Represas ${ }^{74}$, se ha entendido que el carácter indivisible en la transacción no es absoluto, por cuanto la norma que lo consagra sería meramente interpretativa o supletoria de la voluntad de las partes; de forma tal que siempre que exista y resulte debidamente acreditada una voluntad en sentido contrario, debe considerarse divisible a la transacción y por lo tanto admitirse su validez parcial. Se tratará, en suma, de una cuestión de hecho, librada a la apreciación judicial a tenor de las circunstancias particulares de cada

73 Raymundo M. Salvat. Op. cit., Tomo II, p. 289.

74 Pedro N. Cazeaux y Félix A. Trigo Represas. Op. cit., Tomo II, p. 235. 
caso. Recuerdan que en tal sentido, algunos Códigos extranjeros, como los de Uruguay (artículo 2658 ) y México (artículo 2962), sólo atribuyen a la transacción carácter indivisible mientras las partes no hayan convenido lo contrario.

\section{Garantías.}

El segundo párrafo del artículo $1310^{\circ}$ del Código Civil peruano prevé que de presentarse el supuesto analizado, se restablecen las garantías otorgadas por las partes, pero no las prestadas por terceros.

Si la transacción se anulase, el acto dudoso o litigioso permanecería inalterado y la situación de controversia continuaría presente.

Es respecto del acto controvertido -cuya transacción es nula o anulable- que se restablecen las garantías otorgadas por las partes. Sin embargo, la ley no otorga tratamiento similar a las garantías de terceros, las mismas que no se restablecen, ya que lo contrario equivaldría a someter a esas personas a una permanente inestabilidad jurídica.

Solución de controversias a través de la suerte. Aplicación a este supuesto de las normas de la transacción.

El legislador de 1984, con el propósito de estimular la transacción de asuntos dudosos o litigiosos, ha previsto que cuando las partes se sirven de la suerte para dirimir cuestiones, ello produzca los efectos de una transacción (artículo $1311^{\circ}$ del Código Civil).

$\mathrm{Si}$ las partes se someten a la ventura para dirimir sus diferencias, en realidad pueden estar celebrando el denominado "contrato de decisión" por medio de la suerte, acto que, en algunos casos, puede ser adecuadamente una transacción.

Consideramos que el supuesto previsto por el artículo $1311^{\circ}$ del Código Civil constituye propiamente una transacción, ya que se presentan, aunque a primera vista no lo parezca (por la posible confusión con el contrato de decisión), todos los supuestos establecidos para que se configure una transacción.

Si cabe algún cuestionamiento relativo a la existencia de concesiones recíprocas, éstas se dan desde el momento en que las partes aceptan 
solucionar su controversia recurriendo al acaso, vale decir, que admiten -al dejar la solución del problema librado a la suerte- que prevalezca salir beneficiadas o perjudicadas por efectos del azar, lo que constituye una verdadera transacción.

Podemos imaginar muchas maneras a través de las cuales se recurra a solucionar un problema utilizando esta vía. Una de ellas, por citar un ejemplo, sería la de que por medio de la suerte se haga prevalecer finalmente la opinión o parecer de una parte o de la otra, pero por completo. Sería algo así como: "si tú ganas te pago todo lo que tú dices que te debo, pero si pierdes no pago nada, pues sostengo no deber".

Una vez que se determinan los derechos de las partes, las cuestiones sometidas a la suerte producen los efectos de una transacción y su cumplimiento se ejecuta conforme a lo dispuesto en el artículo $1312^{\circ}$ del Código Civil: en la vía ejecutiva, si se trata de derechos dudosos, todavía no litigiosos, y como si fuera una sentencia, para el caso en que haya sido llevada a cabo dentro de un proceso.

Podría ser frecuente, por otro lado, que las partes decidan dejar al azar alguna combinación de concesiones recíprocas sobre cuya elección no se han puesto aún de acuerdo. Por ejemplo, Cristina propone a Eduardo varias alternativas (ofrecimientos), y éste, por su parte, tiene una propuesta para cada una de tales alternativas. Finalmente, existen varias "combinaciones", cada una de las cuales incluye concesiones recíprocas y, por tanto, una potencial transacción. Ante la indecisión, podrían optar porque sea la suerte la que determine cuál constituirá la transacción que ponga fin a su controversia.

Sin embargo, la transacción dejada a la suerte puede revestir características un tanto más complejas.

Uno de los coautores de este trabajo tuvo ocasión de participar hace más de tres décadas en la solución de una controversia suscitada entre seis herederos (todos ellos hijos, en igualdad de porcentajes) de un ciudadano que al fallecer dejó una cuantiosa fortuna.

Era el caso de que prácticamente todos los herederos deseaban, como cuota parte, los mismos bienes, lo que determinaba la imposibilidad de efectuar una división y partición armoniosa. Para solucionar una situación que se tornaba conflictiva, y que a todas luces ya resultaba dudosa, se les sugirió efectuar una división y partición derivada de la suerte.

Así, luego de una escrupulosa tasación de los bienes materia de la herencia, el albacea y asesor legal de los herederos procedió a agrupar 
los bienes de la sucesión en seis lotes, cada uno de valor similar. Luego, en acto que contó con la asistencia de los seis herederos y de notario público, se asignó un número a cada conjunto de bienes, y por sorteo, esto es, por azar, se adjudicó un lote a cada heredero.

En este caso, si bien ninguno logró máximas aspiraciones ideales respecto de los bienes que constituían la masa hereditaria, todos quedaron satisfechos con el resultado del sorteo, el mismo que puso fin a sus controversias y les ahorró considerable tiempo, molestias y dinero.

El caso expuesto demuestra cuán útil puede resultar recurrir al mecanismo de la transacción por medio de la suerte y cuántos problemas se podrían solucionar si ese sistema se utilizara con mayor frecuencia.

\section{Maneras de ejecutar la transacción judicial y extrajudicial.}

El numeral 1312 del Código Civil se encarga de establecer las vías mediante las cuales las personas que hayan transigido pueden ejecutar dicha transacción (o solicitar su cumplimiento). Como podemos ver, la norma distingue dos vías, en función de si la transacción ha sido celebrada dentro de un proceso judicial o fuera de él ${ }^{75}$.

En este punto consideramos necesario recordar que respecto a este numeral la Comisión Revisora del Código Civil Peruano ${ }^{76}$ expresa que la norma responde en sus dos partes a una bien entendida economía procesal, que aconseja adoptar soluciones rápidas, simples y de menor costo económico y social.

(a) Ejecución de la transacción judicial.

Recuerda la Comisión que durante los debates para la aprobación del Código Civil, el doctor Jack Bigio Chrem expresó la conveniencia de que se incorpore un precepto que recoja el criterio prevaleciente de la jurisprudencia nacional, a fin de que la transacción celebrada cuando

75 Arrículo $1312^{\circ}$.- "La transacción judicial se ejecuta de la misma manera que la sentencia y la extrajudicial, en la vía ejecutiva."

76 Comisión Revisora del Código Civil Peruano. Jack Bigio Chrem. Op. cit., pp. 13-15. 
existe un proceso entre las partes, sea ejecutada de la misma manera que la sentencia. Expresó que de esa manera se estimularía a las partes a transigir y se robustecerían los derechos de los que han intervenido en la transacción, al otorgarles un medio expeditivo para obtener su cumplimiento.

Agregó, asimismo, que el Código Civil debía incorporar el precepto a fin de que los litigantes y los jueces tuvieran una regla precisa que evite que surja un conflicto acerca del modo en que deba ejecutarse la transacción que ha puesto fin al proceso.

La transacción judicial constituye -dentro del Código Procesal Civil- el Capítulo III del Título XI, relativo a las Formas Especiales de Conclusión del Proceso.

Cabe señalar que el profuso tratamiento que ha recibido la transacción judicial en el Código Procesal Civil, no siempre guarda relación con las normas de carácter sustantivo de los artículos $1302^{\circ}$ a $1312^{\circ}$ del Código Civil.

En tal sentido, vamos a efectuar una rápida revisión acerca de las normas que sobre transacción judicial contiene el Código Procesal Civil en vigencia (artículos $334^{\circ}$ a $339^{\circ}$ ).

Resulta en extremo importante para efectos de nuestro análisis, lo prescrito por el artículo $337^{\circ}$ del Código Procesal Civil, norma que señala que el juez aprueba la transacción siempre que contenga concesiones recíprocas, verse sobre derechos patrimoniales y no afecte el orden público o las buenas costumbres, y declara concluido el proceso si alcanza a la totalidad de las pretensiones propuestas. Agrega la norma que queda sin efecto toda decisión sobre el fondo que no se encuentre firme.

En lo que respecta a este numeral, debemos subrayar que concuerda con lo prescrito en el artículo $1302^{\circ}$ del Código Civil, al establecer la necesidad de las concesiones recíprocas; al igual que coincide con el artículo $1305^{\circ}$ del referido código, ya que sólo los derechos patrimoniales pueden ser objeto de transacción.

Además, a pesar de que la ley sustantiva no se manifiesta sobre el particular, es interesante ver cómo el artículo $1337^{\circ}$ del Código Procesal Civil establece la conclusión del proceso si la transacción alcanza a la totalidad de las pretensiones propuestas; lo que equivale a decir que sólo pone fin al proceso la transacción cuando tiene carácter total, no así la transacción parcial, pues ella -como vimos oportunamente-solu- 
ciona tan sólo un aspecto del problema materia de litigio o discusión. Se puede decir, entonces, que el Código Procesal Civil reconoce indirectamente la existencia de la transacción parcial, a pesar de que la excluye del ámbito judicial (circunscribiéndose -por tales consideraciones- a la transacción extrajudicial).

De otro lado, también es necesario subrayar que el artículo $337^{\circ}$ del Código Procesal Civil coincide con el último párrafo del artículo $1302^{\circ}$ del Código Civil, en el sentido que la transacción que pone fin al proceso tiene autoridad de cosa juzgada.

Resulta discutible lo dispuesto en la segunda parte del segundo párrafo del artículo $337^{\circ}$ del Código Procesal, cuando señala que el incumplimiento de la transacción no autoriza al perjudicado a solicitar la resolución de ésta. Decimos que es discutible, pues más allá de constituir un medio extintivo de obligaciones, la transacción es un contrato que puede servir para crear, regular o modificar relaciones jurídicas que no necesariamente sean aquellas materia de discusión. En tal sentido, si estuviésemos ante un supuesto de incumplimiento contractual, pensamos que deberían resultar aplicables los preceptos generales de resolución por incumplimiento, plasmados en los artículos $1428^{\circ}, 1429^{\circ}$ y $1430^{\circ}$ del Código Civil. Sin embargo, la ley procesal peruana restringe el ámbito de la transacción, ya que con ella no se pueden crear, regular, modificar o extinguir relaciones materiales ajenas al proceso; en contravención a lo dispuesto por el segundo párrafo del artículo $1302^{\circ} \mathrm{del}$ código sustantivo.

El referido artículo $337^{\circ}$ del Código Procesal Civil establece que si la transacción recae sobre alguna de las pretensiones propuestas o se relaciona con alguna de las personas, el proceso continuará respecto de las pretensiones o personas no comprendidas en ella; caso, este último, en el que se tendrá en cuenta lo normado sobre intervención de terceros.

De otro lado, el Código Procesal Civil señala (artículo 338 ) que en todo lo no previsto en el Capítulo relativo a la transacción judicial, se aplican las normas pertinentes del Código Civil.

Finalmente, el artículo $339^{\circ}$ del Código Procesal establece que aunque hubiera sentencia consentida o ejecutoriada, las partes pueden acordar condonar la obligación que ésta contiene, novarla, prorrogar el plazo para su cumplimiento, convenir una dación en pago y, en general, celebrar cualquier acto jurídico destinado a regular o modificar el 
cumplimiento de la sentencia, pero que dicho acto jurídico no tiene la calidad de transacción ni produce los efectos de ésta.

A pesar de que se podría pensar en la eventual configuración de una transacción en tales circunstancias, por considerar dentro de la categoría conceptual de "asunto dudoso" a la duda respecto de las posibilidades de pago del vencido en pleito judicial, para nosotros es claro que un acto de estas características no podría llegar a revestir la naturaleza jurídica de transacción, por cuanto el asunto "dudoso o litigioso" ya quedó aclarado en la sentencia consentida (lo que equivale a decir que el mismo dejó de tener tales características). Las eventuales coordinaciones posteriores entre las partes que las lleven a un acuerdo podrán constituir novación, dación en pago, condonación, etc., mas nunca una transacción.

Como punto aparte queremos mencionar que es frecuente en las obligaciones pecuniarias en las que los tribunales resolvieron obligar a una parte al pago de intereses, sin anotar o establecer específicamente un monto, que luego se discuta dicho monto en juicio. No obstante ser una sentencia consentida y ejecutoriada, se sigue discutiendo judicialmente, pero podría considerarse que el tema de los intereses (si bien ahora solamente en lo que respecta a su cuantía) continuaría revistiendo el carácter de dudoso.

\section{(b) Ejecución de la transacción extrajudicial.}

La norma (el artículo $1312^{\circ}$ del Código Civil peruano) abarca también a los supuestos en que existan derechos dudosos, pero que no están siendo sometidos a debate judicial. La finalidad, al igual que en la transacción judicial, es agilizar la ejecución de la transacción. Por ello, a fin de asegurar su eficaz cumplimiento, el legislador le atribuyó carácter de título que apareja ejecución, además de la fuerza obligatoria que el ordenamiento jurídico confiere a todo contrato ${ }^{77}$.

77 "Si la norma procesal confiere fuerza ejecutiva al dicho del arrendador en la ejecución por pago de la renta, el legislador estima que con mayor razón debe otorgarse mérito ejecutivo a la transacción extrajudicial -en la que el Juez está en aptitud de apreciar la voluntad del obligado- a fin de asegurar su pronto y eficaz cumplimiento.

Finalmente, cabe tener presente que el artículo $1312^{\circ}$ sólo regula las vías para solicitar el cumplimiento de la transacción. Nada impide que la parte perjudicada por algún incumplimiento pueda solicitar la resolución de la transacción." (Comision Revisora del Código Civil Peruano. Jack Bigio Chrem. Op. cit., pp. 14-15.). 
Una vez entrado en vigencia el Código Procesal Civil que hoy nos rige, desde el 28 de julio de 1993, el tema de la ejecución de la transacción extrajudicial, así como el de la transacción judicial han pasado a tener regulación expresa en el referido cuerpo normativo, quedando derogadas las normas que al respecto recogía el Código de Procedimientos Civiles de 1912, al que hace referencia el análisis de la Comisión Revisora, antes citado.

Como se recuerda, los procesos de ejecución se encuentran regulados en los artículos $688^{\circ}$ y siguientes del Código Procesal Civil.

Dentro del ordenamiento procesal, en virtud de lo prescrito por el artículo $693^{\circ}$, inciso 5, del código adjetivo, norma referente a los títulos ejecutivos, se puede promover proceso ejecutivo en mérito de documento privado que contenga transacción extrajudicial.

Por otra parte, el numeral 694 de dicho código establece que se puede demandar ejecutivamente obligaciones de dar sumas de dinero, de dar bien mueble determinado, de hacer y de no hacer.

El artículo $695^{\circ}$ expresa que a la demanda se acompaña el título ejecutivo, además de los requisitos y anexos previstos en los artículos $424^{\circ}$ y $425^{\circ}$, en lo que corresponda.

Finalmente, a través del artículo $696^{\circ}$ se señala que el Juez de Paz Letrado es competente para conocer las pretensiones cuya cuantía no sea mayor de cincuenta Unidades de Referencia Procesal; siendo competencia del Juez Civil las pretensiones que superen dicho monto.

\section{Transacción y mediación o buenos oficios.}

Antes de concluir con nuestras apreciaciones acerca de la transacción, debemos expresar que la mediación o buenos oficios es un tema no previsto por la ley, pero nada se opone a que opere como tal.

Es frecuente, en efecto, que partes que tienen un asunto dudoso o litigioso designen de común acuerdo a un mediador o a una persona que interponga sus buenos oficios para solucionar el conflicto. Si ante esta interposición ambas partes se hacen concesiones recíprocas, evidentemente se estaría produciendo una transacción.

$\mathrm{Si}$, por el contrario, a través de la mediación o buenos oficios, una de las partes acepta íntegramente las peticiones de la otra parte, entonces estaremos frente a un reconocimiento de obligación que se extin- 
guirá por cualquiera de las otras formas previstas por la ley, principalmente mediante el pago.

\section{Transacción y arbitraje.}

También debemos referirnos al arbitraje. El arbitraje carece de mayores puntos de contacto con la transacción, salvo que un proceso arbitral concluya por esa vía.

Como se sabe, durante el presente siglo el arbitraje estuvo previsto, en primer término, por los artículos $548^{\circ}$ y siguientes del antiguo Código de Procedimientos Civiles. Con posterioridad se complementó por los artículos $1906^{\circ}$ a $1922^{\circ}$ del Código Civil de 1984 . Luego todo su tratamiento fue modificado por el Código Procesal Civil. A continuación se dictó el minucioso Decreto Ley $N^{\circ} 25935$ y, finalmente, hoy todo el proceso arbitral está regido por la Ley General de Arbitraje $N^{\circ}$ 26572, de fecha 20 de diciembre de 1995.

En rasgos generales no es posible someter a arbitraje asuntos relativos al estado o la capacidad civil de las personas, ni sobre los bienes o derechos de incapaces, sin la previa autorización judicial. Tampoco cabe sobre las normas que interesan al orden público o que versan sobre delitos o faltas.

Sin embargo, el arbitraje, -cada vez más difundido en el Perú durante los últimos años, por entidades nacionales especializadas como el Colegio de Abogados de Lima, la Cámara de Comercio de Lima, CEARCO, etc., o por entidades internacionales (como en el caso de la Cámara de Comercio Internacional CCI)- también puede terminar por transacción, tal como ocurre en un proceso judicial.

\section{Transacción y conciliación.}

Podría ser que nos encontrásemos ante un supuesto de conciliación judicial, la misma que constituye otra de las formas especiales de conclusión del proceso, teniendo rasgos característicos en nuestra legislación procesal, los cuales de alguna forma la asemejan a la transacción.

En el artículo $323^{\circ}$ se establece que las partes pueden conciliar su conflicto de intereses en cualquier estado del proceso, siempre que no 
se haya expedido sentencia en segunda instancia (nótese que la transacción judicial procede en cualquier estado del juicio, incluso cuando la causa esté al voto o en discordia en una casación).

Por el artículo $324^{\circ}$ se señala que la conciliación puede ocurrir ante el juez del proceso en la audiencia respectiva, o en la que éste convoque de oficio o cuando lo soliciten las partes para tal efecto; no siendo dicho juez recusable por las manifestaciones que pudiera formular en esta audiencia.

El juez aprobará la conciliación que trate sobre derechos disponibles, siempre que el acuerdo se adecúe a la naturaleza jurídica del derecho en litigio (artículo 325\%).

En virtud del artículo $326^{\circ}$ se señala que estando presentes las partes, o sus apoderados o representantes con capacidad para ello, el juez escuchará por su orden las razones que expongan. De inmediato propondrá la fórmula de conciliación que su prudente arbitrio le aconseje. También puede disponer la suspensión de la audiencia y su posterior reanudación dentro de un plazo no mayor de diez días.

Si la fórmula conciliatoria fuese aceptada, se anotará en el Libro de Conciliaciones que cada órgano jurisdiccional llevará al efecto, dejándose constancia en el expediente. Si la propuesta no es aceptada, se extenderá acta describiéndose la fórmula planteada, mencionándose además la parte que no prestó su conformidad a la misma.

Si la sentencia otorga igual o menor derecho que el que se propuso en la conciliación y fue rechazado, se impone al que lo rechazó una multa no menor de dos ni mayor de diez Unidades de Referencia Procesal, salvo que se trate de proceso de alimentos, en cuyo caso el juez puede reducir la multa en atención al monto demandado y al que se ordena pagar en la sentencia.

De acuerdo al artículo $327^{\circ}$ del Código Procesal Civil, aceptada por las parres la propuesta conciliatoria del juez, si versa sobre todas las pretensiones propuestas, éste declarará concluido el proceso.

Si la conciliación recae sobre alguna de las pretensiones o se refiere a alguno de los litigantes, el proceso continuará respecto de las pretensiones o de las personas no afectadas. En este último caso, se tendrá en cuenta lo normado sobre intervención de terceros.

En virtud a lo establecido por el artículo $328^{\circ}$, la conciliación surte el mismo efecto que la sentencia que tiene autoridad de cosa juzgada (extremo en el que se asemeja a lo dispuesto por la primera parte del 
segundo párrafo del artículo $337^{\circ}$ del Código Procesal Civil, en materia de transacción, y a lo dispuesto por el tercer y último párrafo del artículo $1302^{\circ}$ del Código Civil).

Finalmente, el artículo $329^{\circ}$ del Código Procesal dispone que la copia del acta del Libro de Conciliaciones, certificada por el juez y expedida a solicitud del interesado, es instrumento pleno para el ejercicio de los derechos allí contenidos, así como para su inscripción en el registro que corresponda.

Ahora bien, es de notar que las semejanzas que existen entre esta figura y la transacción son ostensibles, por cuanto ambas tienen como núcleo sustancial el acuerdo pacífico y a satisfacción de ambas partes para eliminar la discrepancia entre ellas.

Pero éste vendría a ser el único punto en común entre ambas figuras jurídicas, por cuanto, como vemos, la conciliación es una alternativa que se presenta dentro de un proceso, ya sea judicial o arbitral, contemplado en la normatividad correspondiente. En cambio, la transacción se da dentro o fuera de un juicio o arbitraje, y cuando se da dentro de un proceso, puede ser en cualquier estado de él, sin necesidad de que las partes soliciten espacio y momento para transigir.

La conciliación, en cambio, debe celebrarse dentro de la audiencia de conciliación (etapa prevista legalmente dentro de un proceso) o por convocatoria de oficio por parte del juez, o cuando a éste lo hubieren solicitado las partes. Finalmente, el juez debe participar en la conciliación, proponer, según el caso, alguna fórmula conciliatoria y aprobar el resultado de la conciliación. En la transacción el juez no tiene injerencia alguna, siendo un acuerdo estrictamente privado de las partes.

No obstante lo expresado, cabe recordar que con fecha 29 de octubre de 1997 se promulgó la Ley No 26872, Ley de Conciliación, publicada en el diario oficial "El Peruano", el día 13 de noviembre de 1997.

Esta Ley declara de interés nacional a la conciliación como mecanismo alternativo de solución de conflictos, "con la finalidad de propiciar una cultura de paz".

Se establece que la conciliación es previa al proceso judicial y necesariamente consensual, en el sentido de que los acuerdos adoptados obedecen única y exclusivamente a la voluntad de las partes.

Podría decirse, en términos muy generales, que la conciliación es un requisito necesariamente previo a los procesos que versen sobre dere- 
chos disponibles de las partes, y ella debe realizarse ante un Centro de Conciliación o ante el Juzgado de Paz Letrado.

También son objeto de conciliación, en cuanto al Derecho de Familia, los alimentos, el régimen de visitas y los casos de violencia familiar, exceptuándose la comisión de delitos o faltas.

Esta nueva forma de conciliación tiene carácter facultativo hasta el día 11 de enero del año 2000, siendo obligatoria a partir de tal fecha.

En otras palabras, ello significa que no se podrá interponer una demanda judicial sobre derechos disponibles o sobre los temas mencionados de Derecho de Familia, si previamente no se acude a intentar la conciliación.

Claro está que como es facultativa, la misma se frustraría si no hubiera acuerdo o si se produjera la inasistencia de una o de ambas partes.

Por último, podría ser que, tratándose de una conciliación extrajudicial (caso que acabamos de mencionar), de existir concesiones recíprocas de las partes que ponen fin al asunto materia de controversia, entonces -en este supuesto- el acuerdo pudiera revestir la naturaleza jurídica de transacción. 
